\title{
Insight into the Factors of Thermal Oxidation Influencing Properties of Iridium Oxide Electrodes
}

\author{
Feifei Huang, ${ }^{1,2 *}$ Peng Bi, ${ }^{3}$ Zhengwei Wan, ${ }^{4}$ \\ Qingrui Wang, ${ }^{1}$ Ying Jin, ${ }^{1,2^{* *}}$ and Lei Wen ${ }^{1,2}$ \\ ${ }^{1}$ National Center for Materials Service Safety, University of Science and Technology Beijing, \\ Beijing 100083, P. R. China \\ ${ }^{2}$ Innovation Group of Marine Engineering Materials and Corrosion Control, Southern Marine Science \\ and Engineering Guangdong Laboratory, Zhuhai 519080, P. R. China \\ ${ }^{3}$ Division of Materials Science and Engineering, Graduate School of Engineering, Hokkaido University, \\ Sapporo 060-8628, Japan \\ ${ }^{4}$ Zhejiang FunLithium New Energy Technology Co., Ltd., Zhejiang 315000, P. R. China
}

(Received June 3, 2020; accepted August 27, 2020)

Keywords: $\mathrm{IrO}_{x} \mathrm{pH}$ electrode, thermal oxidation, relevance among composition, structure and response property

Using thermal oxidation for fabricating iridium oxide $\left(\operatorname{IrO}_{x}\right)$ electrodes is a good choice for obtaining robust $\mathrm{pH}$ electrodes. We fabricated $\mathrm{IrO}_{x}$ electrodes at different temperatures for different heating times to obtain electrodes with different $E$ (electrode potential)-pH responses, response rates, and long-term stability. Corresponding characterizations, which include surface morphology, section morphology and composition, surface composition, and surface roughness, are examined intensively. Scanning electron microscopy (SEM), electrochemical impedance spectroscopy (EIS), and X-ray photoelectron spectroscopy (XPS) are used to carry out the characterizations. All prepared electrodes had a near-Nernstian response, especially when heated at 750,800 , and $870{ }^{\circ} \mathrm{C}$ for 1.0 and $1.5 \mathrm{~h}$. $\operatorname{IrO}_{x}$ electrodes fabricated with these heat treatment parameters had a relatively high response speed, a small potential drift, few cracks on the surface oxide film, thick films, and a small reaction impedance. The surface roughness and composition of the $\mathrm{IrO}_{x}$ electrodes fabricated at different temperatures for $1.5 \mathrm{~h}$ were also obtained to clarify the relationship between the electrode composition, structure, and properties. Finally, the properties of the electrodes and their relationship with technical preparation parameters and the electrode structure and composition are discussed.

\section{Introduction}

$\mathrm{pH}$ is an important parameter not only in fundamental research but also in application fields. The fast and accurate detection of $\mathrm{pH}$ in different environments is of great importance. Although the widely used glass $\mathrm{pH}$ electrodes have good stability and sensitivity, their high input impedance, large volume, and alkaline error limit make $\mathrm{pH}$ detection in

\footnotetext{
*Corresponding author: e-mail: feifeihuang@ustb.edu.cn

** Corresponding author: e-mail: yjin@ustb.edu.cn

https://doi.org/10.18494/SAM.2020.2957
} 
micro-environments and in situ $\mathrm{pH}$ measurements difficult. Researchers have made great effort to develop new types of $\mathrm{pH}$ electrodes, which include metal/metal oxide electrodes, ${ }^{(1-4)}$ optical fiber $\mathrm{pH}$ sensors, ${ }^{(5,6)}$ hydrogel film $\mathrm{pH}$ sensors, ${ }^{(7-11)}$ and ion-sensitive field-effect transistor $\mathrm{pH}$ sensors. $^{(12,13)}$ Among which, metal/metal oxide $\mathrm{pH}$ electrodes have been studied extensively because of their advantages of miniaturization, low input impedance, maintenance, cost, and excellent $\mathrm{pH}$ response.

After a comprehensive assessment carried out by comparing the sensitivity, Nernstian response range, and potential drift of metal/metal oxide electrodes, including $\mathrm{Sb}-\mathrm{Pb}$ oxide, $\mathrm{PtO}_{2}, \mathrm{IrO}_{2}, \mathrm{RuO}_{2}, \mathrm{Ta}_{2} \mathrm{O}_{5}$, and $\mathrm{WO}_{3}$, iridium oxide $\left(\mathrm{IrO}_{x}\right)$ electrodes were found to be the most promising for $\mathrm{pH}$ detection. ${ }^{(14-16)}$

The performance of $\mathrm{IrO}_{x}$ electrodes is determined by the fabrication method used; methods include electrodeposition, ${ }^{(17-19)}$ cyclic voltammetry $(\mathrm{CV}),{ }^{(20-22)}$ radio frequency (RF) magnetron sputtering deposition, ${ }^{(23-27)}$ high-temperature carbonate oxidation, ${ }^{(2,28-31)}$ and thermal oxidation. ${ }^{(14,32-35)}$ The properties and structures of $\mathrm{IrO}_{x}$ electrodes fabricated by different methods differ, among which $\mathrm{IrO}_{x}$ electrodes fabricated by electrodeposition and $\mathrm{CV}$ exhibit a super-Nernstian response with an $E$ (electrode potential)-pH sensitivity higher than $-60 \mathrm{mV} / \mathrm{pH}^{(16)}$ This is because more than one $\mathrm{H}^{+}$takes part in the $\mathrm{H}^{+}$response process. However, the potential of electrodes fabricated by the above methods easily shifts even in short-time application. Moreover, the plating bath used in the electrodeposition is difficult to prepare and maintain. To summarize, the potential stability, film-to-substrate adhesion, and reproducibility of the hydrous surface film fabricated by the two above-mentioned methods are unsatisfactory.

A surface $\mathrm{IrO}_{x}$ film produced by $\mathrm{RF}$ magnetron sputtering deposition is anhydrous, which could provide a near-Nernstian response $(-59.16 \mathrm{mV} / \mathrm{pH})$ and good film-to-substrate adhesion. ${ }^{(23,25)}$ Another important characteristic of the sputtering deposition method is compatibility with microfabrication. Although the electrode potential of the fabricated electrodes strongly depends on the substrate temperature and sputtering parameters, the comprehensive cost of the sputtering process is high.

High-temperature carbonate melt oxidation and thermal oxidation are other methods for fabricating $\mathrm{IrO}_{x}$ electrodes that have been widely studied. Yao and coworkers ${ }^{(28,29)}$ and Chen et al. ${ }^{(30)}$ fabricated $\mathrm{IrO}_{x}$ electrodes by high-temperature carbonate melt oxidation, which showed a similar near-Nernstian response to $\mathrm{IrO}_{x}$ electrodes fabricated by $\mathrm{RF}$ magnetron sputtering deposition. The large potential drift caused by hydration and the large deviation even among the different electrodes fabricated by the same method are drawbacks of the above electrodes. Despite these disadvantages, the reproducibility of the $E-\mathrm{pH}$ sensitivity of the fabricated electrodes is achievable. Pan et al. ${ }^{(36)}$ improved this carbonate melt oxidation method by adding sodium peroxide $\left(\mathrm{Na}_{2} \mathrm{O}_{2}\right)$ powder into a $\mathrm{Li}_{2} \mathrm{CO}_{3}$ melt, resulting in good linearity in the $\mathrm{pH}$ range of 2-10 with good stability for $48 \mathrm{~h}$. There have been few reports of $\mathrm{IrO}_{x}$ electrodes with long-term stability, which is their key drawback. Our group proposed a new isothermal heat treatment and quenching process to further improve the performance of $\operatorname{IrO}_{x}$ electrodes. By employing this method, the fabricated $\mathrm{IrO}_{x}$ electrodes illustrate a wide $E-\mathrm{pH}$ range, excellent linearity in the $\mathrm{pH}$ range of $1-13$, near-Nernstian response sensitivity, and good stability for as long as 3 months. ${ }^{(14)}$ We also found that heat treatment conditions impact both 
the surface morphology and uniformity of the electrodes, which will affect their stability and response rate.

Thus far, research on $\mathrm{IrO}_{x} \mathrm{pH}$ electrodes has mainly concentrated on optimizing the preparation and examining the properties of the electrodes fabricated by a specified process. From the above literature review, employing thermal oxidation to fabricate $\operatorname{IrO}_{x} \mathrm{pH}$ electrodes is advantageous. However, the relationships among the fabrication conditions, structure, composition, and properties of $\mathrm{IrO}_{x}$ electrodes have not been clarified. There has been insufficient study of how factors such as heating temperature and heating time affect the thermal oxidation of $\mathrm{IrO}_{x}$ electrodes. Therefore, it is necessary to explore how thermal oxidation parameters affect the fabrication of $\mathrm{IrO}_{x}$ electrodes, excavate the correlation among the fabrication conditions, structure, composition, and performance of the $\mathrm{IrO}_{x}$ electrodes, and finally provide guidelines for the design, fabrication, and application of $\mathrm{IrO}_{x}$ electrodes.

In this study, $\mathrm{IrO}_{x} \mathrm{pH}$ electrodes fabricated with different temperatures $(700,750,800$, and $\left.870{ }^{\circ} \mathrm{C}\right)$ and heating times $(0.5,1,1.5$, and $2 \mathrm{~h}$ ) were investigated in detail by evaluating their $E-\mathrm{pH}$ response, response rate, and long-term stability. Corresponding characterizations of the fabricated electrodes, including surface morphology, section morphology, surface and section composition, and surface roughness, were examined intensively through scanning electron microscopy (SEM), X-ray photoelectron spectroscopy (XPS), and so forth. The surface roughness and composition of the electrodes with the best properties under each fabricated temperature were also examined. Finally, the properties of the electrodes and their relevance with the preparation technical parameters, electrode structure, and compositions were discussed.

\section{Experimental Procedure}

\subsection{Fabrication of $\operatorname{IrO}_{x}$ electrodes}

Iridium wires of $0.5 \mathrm{~mm}$ diameter and about $10 \mathrm{~mm}$ length ( $99.9 \%$ purity) were ultrasonically cleaned in concentrated $\mathrm{HCl}$ for $15 \mathrm{~min}$, then washed with deionized water before being soaked in $5 \mathrm{M} \mathrm{NaOH}$ solution for $24 \mathrm{~h}$. The wet iridium wires were positioned in an alumina crucible, which was then placed in a medium-temperature muffle furnace in air ambience. After that, the iridium wires were oxidized for $0.5,1.0,1.5$, or $2.0 \mathrm{~h}$ in air at $700,750,800$, or $870{ }^{\circ} \mathrm{C}$, which was promptly followed by quenching in deionized water at room temperature. Afterwards, the oxidized iridium wires were soaked and hydrated in deionized water for 2 days. As a result, a dark-blue, cohesive iridium oxide film (IROF) was formed on the surface of each iridium wire. At least three parallel samples were fabricated under the same oxidation conditions, and all the fabricated samples were measured in the same analysis. The fabricated $\mathrm{IrO}_{x}$ electrodes were stored in deionized water when not used.

\subsection{Electrochemical tests}

Buffer solutions made of $0.01 \mathrm{M} \mathrm{H}_{3} \mathrm{PO}_{4}, 0.01 \mathrm{M} \mathrm{H}_{3} \mathrm{BO}_{3}, 0.01 \mathrm{M} \mathrm{CH}_{3} \mathrm{COOH}$, and $0.1 \mathrm{M} \mathrm{KCl}$ with $\mathrm{pH}$ adjusted in the range from 3 to 11 using $0.1 \mathrm{M} \mathrm{NaOH}$ and $0.1 \mathrm{M} \mathrm{HCl}$ were prepared 
and calibrated with a high-precision digital meter glass $\mathrm{pH}$ electrode. The open-circuit potential (OCP) of the $\mathrm{IrO}_{x}$ electrodes in different $\mathrm{pH}$ buffers was measured against a saturated calomel electrode (SCE) using a CHI760D potentiostat (Shanghai Chenhua). Electrochemical impedance spectroscopy (EIS) tests were performed in acid and alkaline pH buffers with a high-resolution electrochemical workstation (Gamry Reference 600) using a platinum electrode as the counter electrode and the SCE as the reference electrode. The EIS tests were performed by applying an $\mathrm{AC}$ voltage signal with an amplitude of $\pm 5 \mathrm{mV}$ and a scanning frequency range from $10 \mathrm{mHz}$ to $100 \mathrm{kHz}$ to the fabricated electrodes. The EIS tests were repeated three times for each fabricated electrode, and similar curves could be observed; the repeatability of the experiments was good for each fabricated condition. ZsimpWin software (Princeton Applied Research) was utilized to fit the obtained impedance data. All the electrochemical tests were carried out at room temperature of $24 \pm 2{ }^{\circ} \mathrm{C}$.

\subsection{Characterizations of the fabricated $\operatorname{IrO}_{x}$ electrodes}

A SEM device (ZEISS SUPRA55) was used to characterize the surface and cross-sectional morphologies of the fabricated IROFs. The composition analysis was realized through energy-dispersive spectroscopy (EDS, ZEISS SUPRA55) with an operating voltage of $20 \mathrm{kV}$.

Surface roughness was observed and analyzed using a 3D measuring confocal laser scanning microscopy (CLSM) devise (LEXT OLS5000) with the average value obtained from the linear scan at five different randomly selected positions for each $\operatorname{IrO}_{x}$ electrode. XPS (AXIS ULTRA DLD) of the fabricated $\mathrm{Ir} / \mathrm{IrO}_{x}$ electrodes was performed by $\mathrm{Al} \mathrm{K \alpha}$ irradiation as the photo source. Wide XPS spectra of the fabricated $\mathrm{IrO}_{x}$ electrodes were first collected, followed by high-resolution XPS spectra of Ir $4 \mathrm{f}$ and $\mathrm{O}$ 1s. Binding energies (BEs) of the obtained spectra were calibrated with the $\mathrm{C}$ 1s standard electron peak at $284.8 \mathrm{eV}$. To further evaluate the obtained data, Xpspeak41 software was used to deconvolute the photoelectron peaks, processing graphically within the constraints of Gaussian/Lorentzian peak shapes.

\section{Results and Discussion}

\subsection{Property examination of the $\mathrm{IrO}_{x}$ electrodes}

\subsection{1 $E-\mathrm{pH}$ response of the fabricated $\mathrm{IrO}_{x}$ electrodes}

The potential-time curves of the $\mathrm{IrO}_{x}$ electrodes fabricated at $700,750,800$, and $870{ }^{\circ} \mathrm{C}$ for $0.5,1.0,1.5$, and $2.0 \mathrm{~h}$ were obtained in different $\mathrm{pH}$ buffers with $\mathrm{pH}$ ranging from 3 to 11 . Then, the $E-\mathrm{pH}$ relationships of the fabricated electrodes were acquired and are illustrated in Figs. 1(a)-1(d). As shown in Fig. 1, regardless of the thermal treatment conditions of the fabricated electrodes, the $E-\mathrm{pH}$ sensitivities obtained by fitting are all within $-54--57 \mathrm{mV} / \mathrm{pH}$, which is close to the theoretical value of $-59.16 \mathrm{mV} / \mathrm{pH}$ for a Nernstian response, and the obtained linear fitting correlation coefficient $R^{2}$ values are all larger than 0.99 . Note that the $E-\mathrm{pH}$ relationships obtained by our method are satisfactory and superior to other previously 

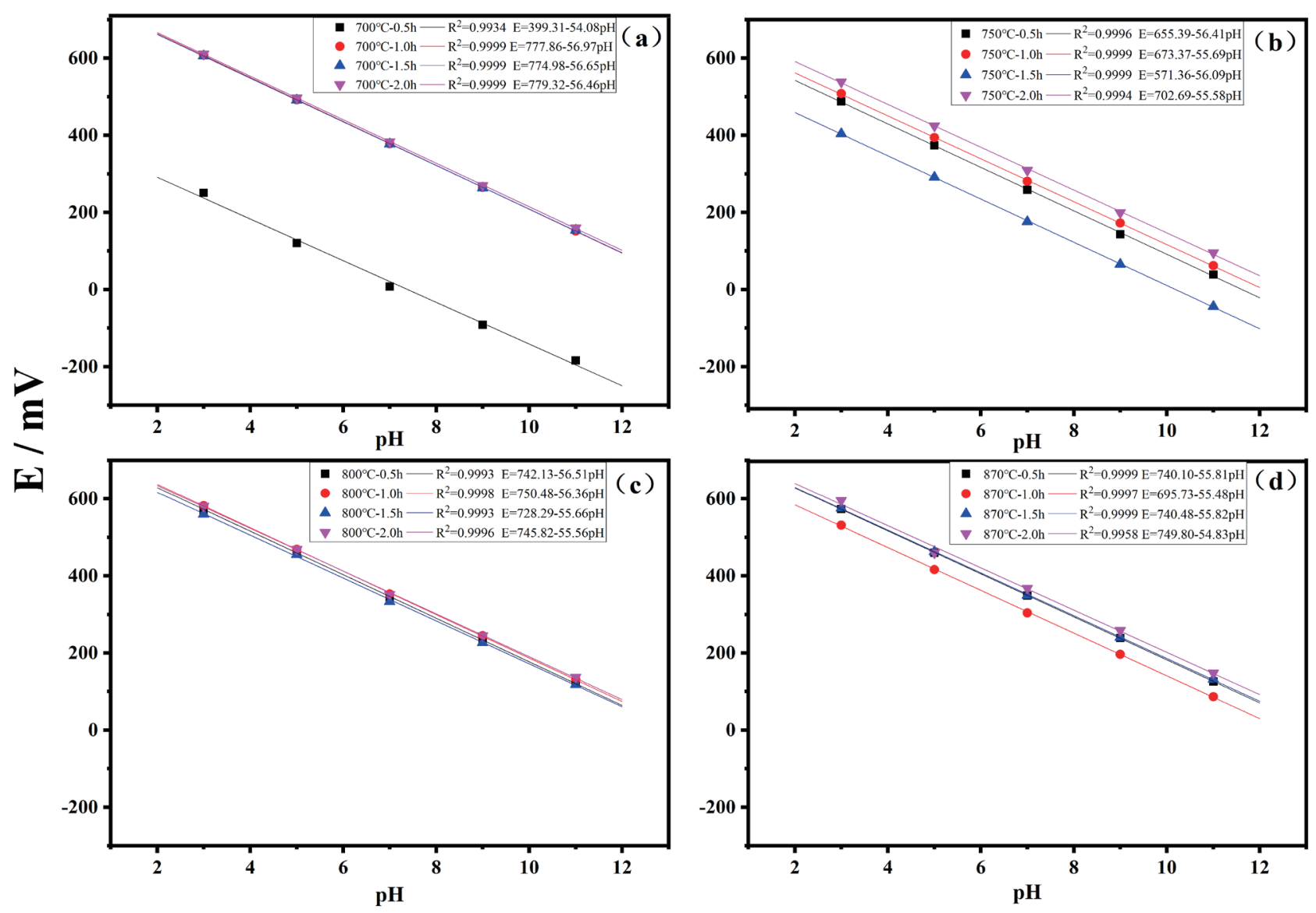

Fig. 1. (Color online) $E-\mathrm{pH}$ relationships of $\mathrm{IrO}_{x}$ electrodes fabricated at (a) 700, (b) 750 , (c) 800 , and (d) $870{ }^{\circ} \mathrm{C}$ with heating times of $0.5,1.0,1.5$, and $2.0 \mathrm{~h}$.

reported relationships. ${ }^{(1,2,36)}$ This may be ascribed to the suitable heat treatment conditions resulting in an appropriate composition of the surface $\mathrm{IrO}_{x}$ film.

Except for the electrode with the heating temperature of $700{ }^{\circ} \mathrm{C}$ and heating time of $0.5 \mathrm{~h}$ and that with the heating temperature of $870{ }^{\circ} \mathrm{C}$ and heating time of $2.0 \mathrm{~h}$, the $R^{2}$ values are larger than 0.999. Among all the fabricated electrodes, those fabricated at $800{ }^{\circ} \mathrm{C}$ with different heating times have the smallest potential difference. As we previously investigated, the electrode potential is determined by the $\mathrm{Ir}^{4+} / \mathrm{Ir}^{3+}$ ratio. ${ }^{(32,33)}$ Therefore, this electrode potential difference phenomenon is attributed to the appropriate heat treatment temperature (i.e., $800{ }^{\circ} \mathrm{C}$ ) generating a similar $\mathrm{Ir}^{4+} / \mathrm{Ir}^{3+}$ ratio in the surface film of the electrodes.

\subsubsection{Response rate of the fabricated $\mathrm{IrO}_{x}$ electrodes}

The response rate of an electrode is a very important index for its application. Especially when electrodes fabricated by different heat treatment processes show similar $E-\mathrm{pH}$ relationships, comparing the response rates of the as-prepared electrodes becomes necessary. As stipulated by the International Union of Pure and Applied Chemistry (IUPAC), when the rate of change of the electrode potential decreases to less than $1 \mathrm{mV} / \mathrm{min}$, the electrode can be 
regarded as achieving a steady state. ${ }^{(37)}$ Therefore, to meet this criterion, the response time of the electrode is defined by the time period needed for the stabilization of the electrode potential.

The potential-time curves in different $\mathrm{pH}$ buffer solutions were obtained to evaluate the $\mathrm{pH}$ response rate of the fabricated electrodes. The response time calculated by the above method was recorded. Figure 2 illustrates the response time and corresponding error bar (standard deviation) distribution maps of the $\mathrm{IrO}_{x}$ electrodes prepared with different heating temperatures and heating time periods in different $\mathrm{pH}$ buffers. It is found that all the fabricated $\mathrm{IrO}_{x}$ electrodes can respond quickly in the $\mathrm{pH}$ buffer solutions, especially in nearly neutral, weakly acidic, and weakly alkaline solutions. Specifically, the average response time of the $\mathrm{IrO}_{x}$ electrodes fabricated at $700{ }^{\circ} \mathrm{C}$ is the longest. The electrodes fabricated at $870{ }^{\circ} \mathrm{C}$ for different heating times have a large difference in response time, e.g., some of the electrodes could become stable within $20 \mathrm{~s}$, while others need more than $150 \mathrm{~s}$ to become stable. The $\operatorname{IrO}_{x}$ electrodes heated for $1.5 \mathrm{~h}$ at different temperatures $\left(700,750,800\right.$, and $\left.870{ }^{\circ} \mathrm{C}\right)$ exhibit the highest response rate and the smallest response time difference.

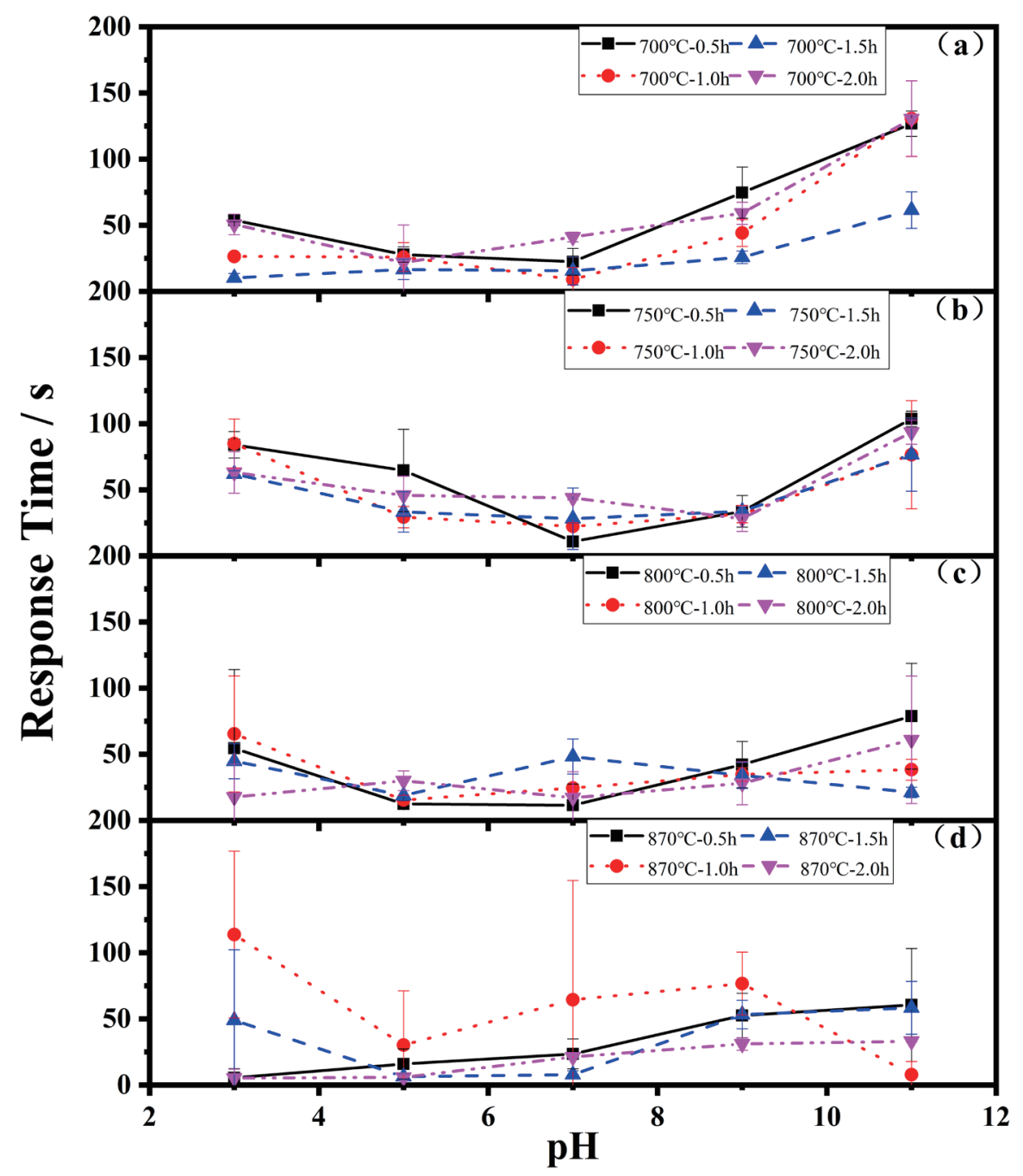

Fig. 2. (Color online) Response time measured in different $\mathrm{pH}$ buffer solutions for the $\mathrm{IrO}_{x}$ electrodes fabricated at (a) 700 , (b) 750 , (c) 800 , and (d) $870{ }^{\circ} \mathrm{C}$ with heating times of $0.5,1.0,1.5$, and $2.0 \mathrm{~h}$. 


\subsubsection{Long-term stability of the fabricated $\mathrm{IrO}_{x}$ electrodes}

Long-term stability is a significant parameter for evaluating the performance of $\mathrm{pH}$ electrodes. The electrode potentials of $\mathrm{IrO}_{x} \mathrm{pH}$ electrodes fabricated at 700, 750, 800, and $870{ }^{\circ} \mathrm{C}$ and heated for $0.5,1.0,1.5$, and $2 \mathrm{~h}$ after immersion in deionized water for 15,45 , and $90 \mathrm{~d}$ were measured in different $\mathrm{pH}$ buffers. The obtained $E-\mathrm{pH}$ relationships of the fabricated electrodes could be similarly plotted in Fig. 1 but are not shown here. The long-term performance parameters including the $E-\mathrm{pH}$ intercept, potential drift, $E-\mathrm{pH}$ sensitivity, $E-\mathrm{pH}$ change, and linear fitting coefficient of the $\mathrm{IrO}_{x}$ electrodes before/after 3 months of immersion are summarized in Table 1 for comparison. The electrode potential distributions versus time over 3 months in a pH 3 or $\mathrm{pH} 11$ buffer for the electrodes fabricated under the above conditions are correspondingly shown in Fig. 3.

The results of long-term potential monitoring illustrated in Figs. 3(a)-3(d) show that the electrode potential of the $\mathrm{IrO}_{x}$ electrode drift varies from 160.40 to $417.90 \mathrm{mV}$ (Table 1). The results in Table 1 also show that increasing the heating time appropriately (from 0.5 to 1.0 and $1.5 \mathrm{~h})$ at a certain temperature can decrease the potential shift except for the electrodes heated at $700{ }^{\circ} \mathrm{C}$ for $1.0 \mathrm{~h}$ and at $870{ }^{\circ} \mathrm{C}$ for $1.5 \mathrm{~h}$. At the same time, the response sensitivities shown in Table 1 change within the $0.03-7.67 \mathrm{mV} / \mathrm{pH}$ range, whereas the linear fitting coefficients are maintained even after immersion in deionized water for $90 \mathrm{~d}$.

The electrode potential of almost all the electrodes decreases with time except for the electrode heated at $700{ }^{\circ} \mathrm{C}$ for $0.5 \mathrm{~h}$ [Fig. 3(b), -]. As proposed in the previous study, the electrode potential of the $\mathrm{IrO}_{x}$ electrode is only determined by the $\mathrm{Ir}^{4+} / \mathrm{Ir}^{3+}$ ratio and the hydration degree of the electrode. With increasing storage period in deionized water, the drift of the electrode potential for each electrode decreases gradually, indicating the variation of the

Table 1

Long-term performance parameters of $\mathrm{IrO}_{x}$ electrodes after immersion in deionized water for $90 \mathrm{~d}$. Electrodes were fabricated with heating at $700,750,800$, or $870{ }^{\circ} \mathrm{C}$ for $0.5,1.0,1.5$, or $2.0 \mathrm{~h}$.

\begin{tabular}{|c|c|c|c|c|c|c|c|c|c|}
\hline \multirow{2}{*}{\multicolumn{2}{|c|}{$\begin{array}{l}\text { Heat treatment } \\
\text { conditions }\end{array}$}} & \multicolumn{2}{|c|}{$E_{\text {intercept }}(\mathrm{mV})$} & \multirow{2}{*}{$\begin{array}{l}\text { Potential } \\
\text { drift }(\mathrm{mV})\end{array}$} & \multicolumn{2}{|c|}{$E-\mathrm{pH}(\mathrm{mV} / \mathrm{pH})$} & \multirow{2}{*}{$\begin{array}{c}E-\mathrm{pH} \text { change } \\
(\mathrm{mV} / \mathrm{pH})\end{array}$} & \multicolumn{2}{|c|}{$\begin{array}{c}\text { Linear fitting } \\
\text { coefficient }\end{array}$} \\
\hline & & $2 \mathrm{~d}$ & $90 \mathrm{~d}$ & & $2 \mathrm{~d}$ & $90 \mathrm{~d}$ & & $2 \mathrm{~d}$ & $90 \mathrm{~d}$ \\
\hline \multirow{4}{*}{$700^{\circ} \mathrm{C}$} & $0.5 \mathrm{~h}$ & 399.31 & 559.71 & -160.40 & -54.08 & -54.25 & 0.17 & 0.9934 & 0.9999 \\
\hline & $1.0 \mathrm{~h}$ & 777.86 & 486.24 & 291.62 & -56.97 & -57.27 & 0.30 & 0.9999 & 0.9994 \\
\hline & $1.5 \mathrm{~h}$ & 774.98 & 648.29 & 126.69 & -56.65 & -55.12 & -1.53 & 0.9999 & 0.9999 \\
\hline & $2.0 \mathrm{~h}$ & 779.32 & 667.63 & 111.69 & -56.46 & -55.13 & -1.33 & 0.9999 & 0.9998 \\
\hline \multirow{4}{*}{$750{ }^{\circ} \mathrm{C}$} & $0.5 \mathrm{~h}$ & 655.39 & 350.34 & 305.05 & -56.41 & -53.20 & -3.21 & 0.9996 & 0.9997 \\
\hline & $1.0 \mathrm{~h}$ & 673.37 & 390.31 & 283.06 & -55.69 & -55.72 & 0.03 & 0.9999 & 0.9630 \\
\hline & $1.5 \mathrm{~h}$ & 571.36 & 409.13 & 162.23 & -56.09 & -51.65 & -4.44 & 0.9999 & 0.9998 \\
\hline & $2.0 \mathrm{~h}$ & 702.69 & 342.91 & 359.78 & -55.58 & -49.40 & -6.18 & 0.9994 & 0.9946 \\
\hline \multirow{4}{*}{$800^{\circ} \mathrm{C}$} & $0.5 \mathrm{~h}$ & 742.13 & 331.29 & 410.84 & -56.51 & -47.44 & -9.07 & 0.9993 & 0.9910 \\
\hline & $1.0 \mathrm{~h}$ & 750.48 & 442.93 & 307.55 & -56.36 & -53.36 & -3.00 & 0.9998 & 0.9967 \\
\hline & $1.5 \mathrm{~h}$ & 728.29 & 371.48 & 356.81 & -55.66 & -47.99 & -7.67 & 0.9993 & 0.9944 \\
\hline & $2.0 \mathrm{~h}$ & 745.82 & 358.75 & 387.07 & -55.56 & -51.61 & -3.95 & 0.9996 & 0.9948 \\
\hline \multirow{4}{*}{$870^{\circ} \mathrm{C}$} & $0.5 \mathrm{~h}$ & 740.10 & 373.83 & 366.27 & -55.81 & -51.29 & -4.52 & 0.9999 & 0.9995 \\
\hline & $1.0 \mathrm{~h}$ & 695.73 & 375.70 & 320.03 & -55.48 & -51.67 & -3.81 & 0.9997 & 0.9991 \\
\hline & $1.5 \mathrm{~h}$ & 740.48 & 322.58 & 417.90 & -55.82 & -52.49 & -3.33 & 0.9999 & 0.9999 \\
\hline & $2.0 \mathrm{~h}$ & 749.80 & 444.19 & 305.61 & -54.83 & -52.63 & -2.20 & 0.9958 & 0.9999 \\
\hline
\end{tabular}



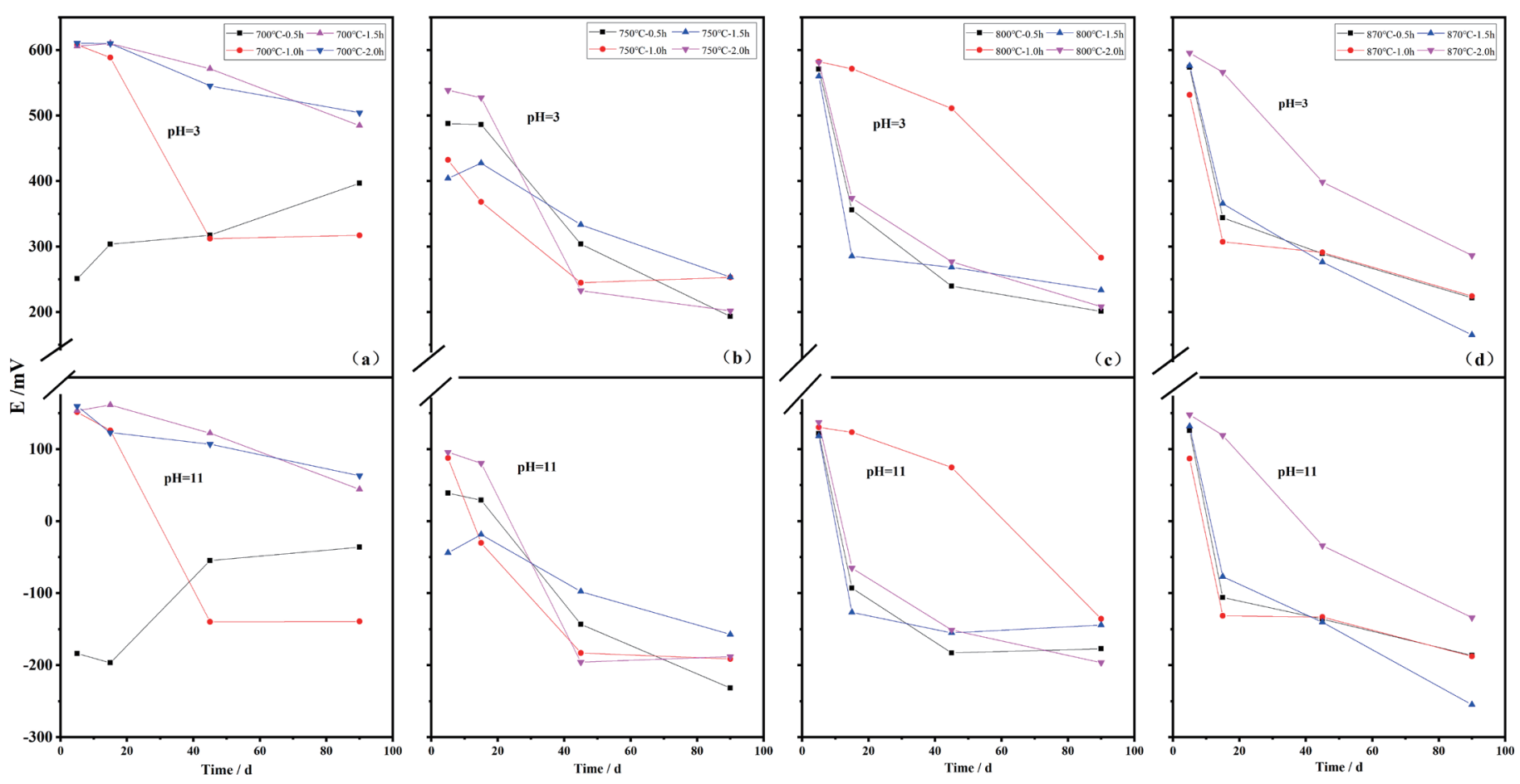

Fig. 3. (Color online) Long-term stability of $\mathrm{IrO}_{x}$ electrodes heated at $700,750,800$, and $870{ }^{\circ} \mathrm{C}$ for $0.5,1.0,1.5$, and $2.0 \mathrm{~h}$ in $\mathrm{pH} 3$ and $\mathrm{pH} 11$ buffers over 3 months.

two above-mentioned factors. The absolute value of the $\mathrm{IrO}_{x}$ electrode will not change or will slightly change within a certain time period no matter how many tests are taken. The above phenomenon indicates the increased lifetime and practicability of the $\operatorname{IrO}_{x}$ electrodes fabricated by the proposed method.

\subsection{Characterizations of the $\mathrm{IrO}_{x}$ electrodes}

\subsubsection{Surface morphology of the fabricated $\operatorname{IrO}_{x}$ electrodes}

The structure of the material has a crucial effect on its performance; therefore, it is necessary to inspect the microstructure of the $\mathrm{IrO}_{x}$ electrodes fabricated under different heat treatment conditions. The surface morphologies of the $\mathrm{IrO}_{x}$ electrodes fabricated at $700,750,800$, and $870{ }^{\circ} \mathrm{C}$ for $0.5,1.0,1.5$, and $2.0 \mathrm{~h}$ are shown in Figs. 4-1-4-4.

As shown in Figs. 4-1-4-4, the surface film of all the fabricated $\operatorname{IrO}_{x}$ electrodes is made up of particles with sizes ranging from $10 \mathrm{~nm}$ to micrometer order. When the heat treatment temperature is $700{ }^{\circ} \mathrm{C}$, with increasing heating time, the particles on the surface of the electrode grow gradually to form a multilayer structure. Cracks can be seen in the electrode surface film, the number and size of which increased markedly with the heating time. For the electrodes fabricated at $750{ }^{\circ} \mathrm{C}$, the particles on the electrode surface become refined as the heating time increases. The smaller the particle size, the clearer the multilayer structure. When the 

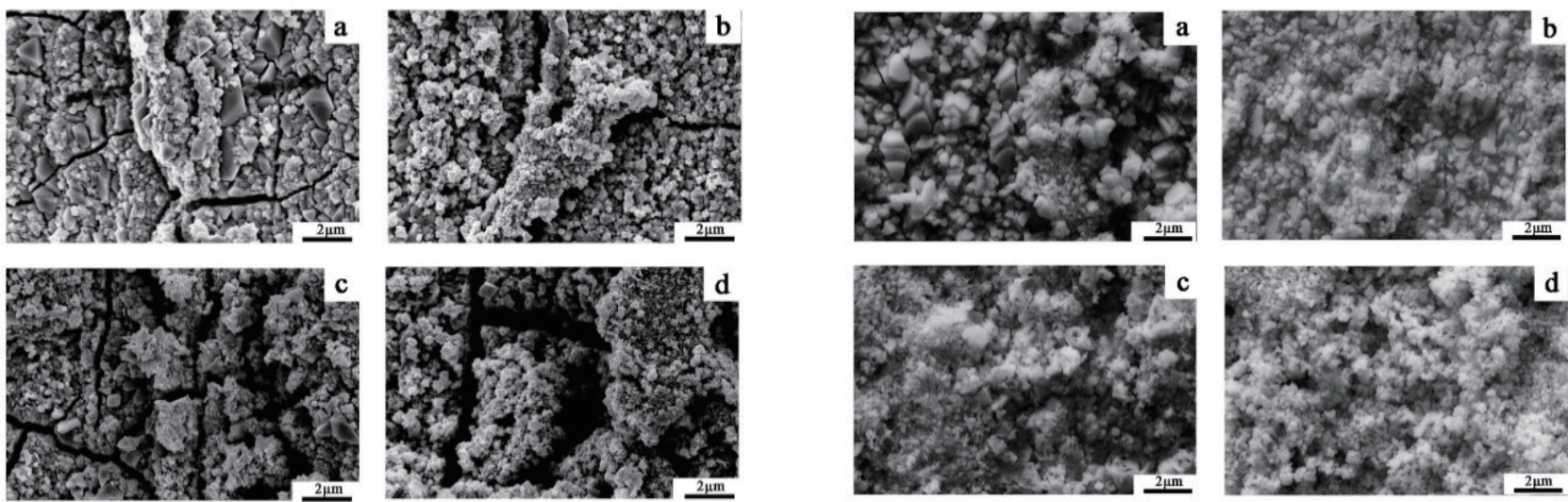

$(4-1)$

$(4-2)$
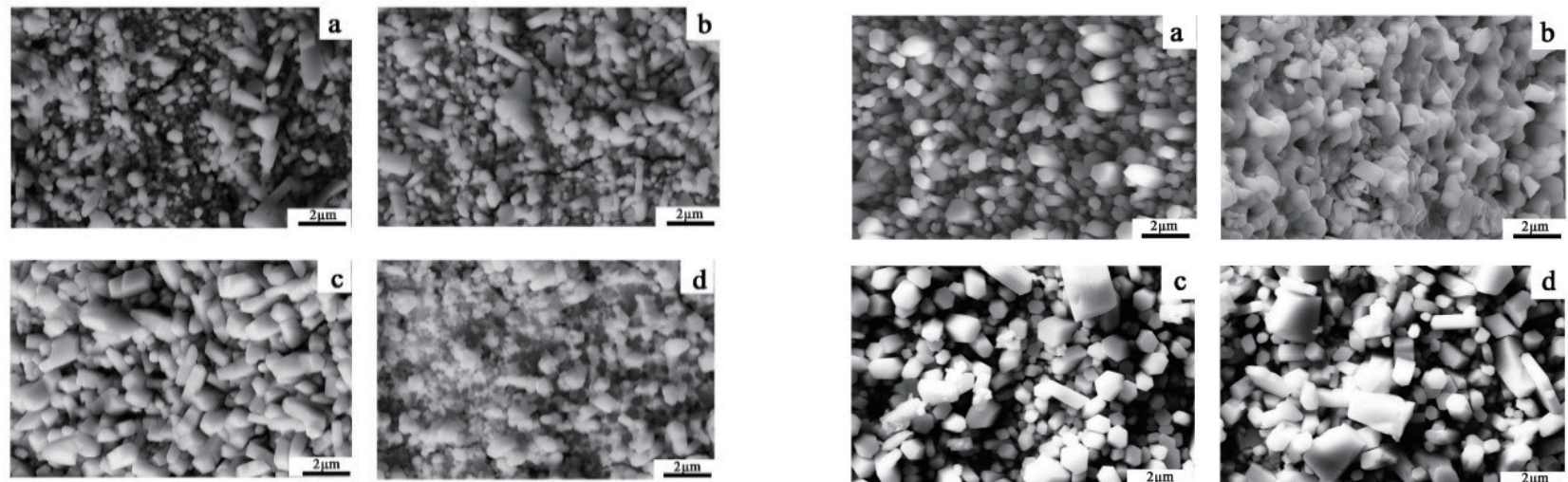

$(4-3)$

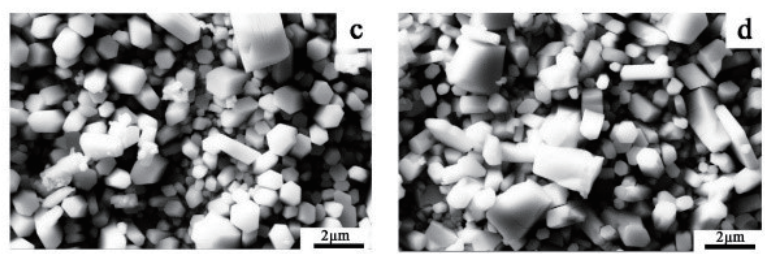

$(4-4)$

Fig. 4. Surface morphologies of the $\mathrm{IrO}_{x}$ electrodes heated at (4-1) 700, (4-2) 750, (4-3) 800, and (4-4) $870{ }^{\circ} \mathrm{C}$ for (a) 0.5 , (b) 1.0, (c) 1.5 , and (d) $2 \mathrm{~h}$.

samples are heated at $800{ }^{\circ} \mathrm{C}$, the particles on the electrode surface tend to be more uniform with increasing heating time, and the particles on the surface film are larger than those for the samples fabricated at $750{ }^{\circ} \mathrm{C}$. For all the samples heated at $870{ }^{\circ} \mathrm{C}$, the particles on the electrode surface continue growing with increasing time, resulting in an irregular structure.

Although cracks in the surface of the oxide film can increase the specific surface reaction area of the oxide film during the response process, considering the applicability of the electrodes in severe environments, a rigid electrode is necessary. Therefore, there should be few cracks in the $\mathrm{IrO}_{x}$ film surface. By observing the surface morphology of the $\mathrm{IrO}_{x}$ films fabricated under different conditions, it is found that when the heat treatment temperatures are 750 and $800{ }^{\circ} \mathrm{C}$, the obtained $\mathrm{IrO}_{x}$ electrode surfaces have relatively few cracks with uniform particles distributed on the surface films.

\subsubsection{Section morphology and EDS analysis of the fabricated $\operatorname{IrO}_{x}$ electrodes}

To investigate the effects of the heat treatment conditions on the thickness and composition of the $\mathrm{IrO}_{x}$ electrodes, section morphologies of the $\mathrm{IrO}_{x}$ electrodes fabricated under the above 
conditions were examined and the corresponding EDS profiles along the depth direction were obtained, the results of which are shown in Figs. 5-1-5-4. The film thicknesses of the fabricated $\mathrm{IrO}_{x}$ electrodes are also given; these thicknesses were obtained by averaging the measured thickness at five places in the film in each selected field, including the minimum, maximum, and three randomly selected fields of the film.

With increasing thermal oxidation temperature and heating time, the thickness of the $\operatorname{IrO}_{x}$ film usually increases. The thicknesses were in the range of $1.2-3.8 \mu \mathrm{m}$ at $700{ }^{\circ} \mathrm{C}, 1.9-4.1 \mu \mathrm{m}$ at $750{ }^{\circ} \mathrm{C}, 3.0-5.8 \mu \mathrm{m}$ at $800{ }^{\circ} \mathrm{C}$, and $1.6-5.6 \mu \mathrm{m}$ at $870{ }^{\circ} \mathrm{C}$. It can be seen from Fig. 5 that the $\mathrm{IrO}_{x}$ film grows gradually with increasing heating time to $1.5 \mathrm{~h}$ at each temperature. Generally, when the heating time is constant, the thickness of the $\mathrm{IrO}_{x}$ film increases with the heating temperature up to $800{ }^{\circ} \mathrm{C}$. However, the electrodes heated at $750{ }^{\circ} \mathrm{C}$ for $2.0 \mathrm{~h}$ and at $870{ }^{\circ} \mathrm{C}$ for $2.0 \mathrm{~h}$ showed different behaviors: the $\mathrm{IrO}_{x}$ film obtained by heating for $2.0 \mathrm{~h}$ is thicker than that obtained by heating for $1.5 \mathrm{~h}$. This may be attributable to differences among individual electrodes, oxygen deficiency, or other reasons that need to be further clarified. Therefore, a longer heating time may not correspond to a thicker surface film. From the appearance of the $\mathrm{IrO}_{x}$ electrodes, the films of the electrodes fabricated at 700 and $750{ }^{\circ} \mathrm{C}$ are incomplete and not uniform. With increasing heating temperature and heating time, the $\mathrm{IrO}_{x}$ film becomes more integrated.

According to the results of EDS composition analysis of the films, the element content distributions of iridium and oxygen in the fabricated $\mathrm{IrO}_{x}$ films generally decrease and increase with increasing distance from the Ir substrate, respectively. The stoichiometry (atom ratio of $\mathrm{O} / \mathrm{Ir}$ ) of the $\mathrm{IrO}_{x}$ films increases with the heating temperature up to $800{ }^{\circ} \mathrm{C}$, indicating a more complete oxidation of the Ir wires, but does not increase further for the film heated at $870{ }^{\circ} \mathrm{C}$. The stoichiometry does not show significant variation among the electrodes fabricated at a certain temperature. Owing to the insufficient oxidation of the Ir wires or the epoxy resin embedded into the porous $\mathrm{IrO}_{x}$ film during the preparation of the coupons for sectional SEM and EDS observations, the atom ratio of $\mathrm{O} / \mathrm{Ir}$ deviated from that of $\mathrm{IrO}_{2}$.

In addition, the adhesion of the surface $\mathrm{IrO}_{x}$ film improved with increasing heating temperature. Gottesfeld et al. found that a thicker $\mathrm{IrO}_{x}$ film exhibited better performance and repeatability; ${ }^{(22)}$ therefore, a surface $\mathrm{IrO}_{x}$ film with a suitable thickness is necessary. As expected, our studies reveal that a thicker porous outer layer results in a larger surface area and a better response. An $\mathrm{IrO}_{x}$ electrode with a thicker surface film was obtained by direct thermal oxidation with a heating temperature higher than $750{ }^{\circ} \mathrm{C}$ and a heating time longer than $1.0 \mathrm{~h}$.

\subsubsection{EIS tests of the fabricated $\mathrm{IrO}_{x}$ electrodes}

The $\mathrm{IrO}_{x}$ electrodes fabricated by direct thermal oxidation at different temperatures for different times exhibited different response rates. To investigate the reason for the different response rates among the fabricated $\mathrm{IrO}_{x}$ electrodes and their dynamic behaviors, EIS tests were conducted on the $\mathrm{IrO}_{x}$ electrodes in $\mathrm{pH} 4$ and $\mathrm{pH} 11$ buffers, and the experimental and fitting data are plotted as Nyquist plots in Fig. 6.

Small arcs can be observed in the high-frequency band shown in the insets in Fig. 6, and the existence of two arcs in the Nyquist plots was confirmed. The arcs in the high-frequency 

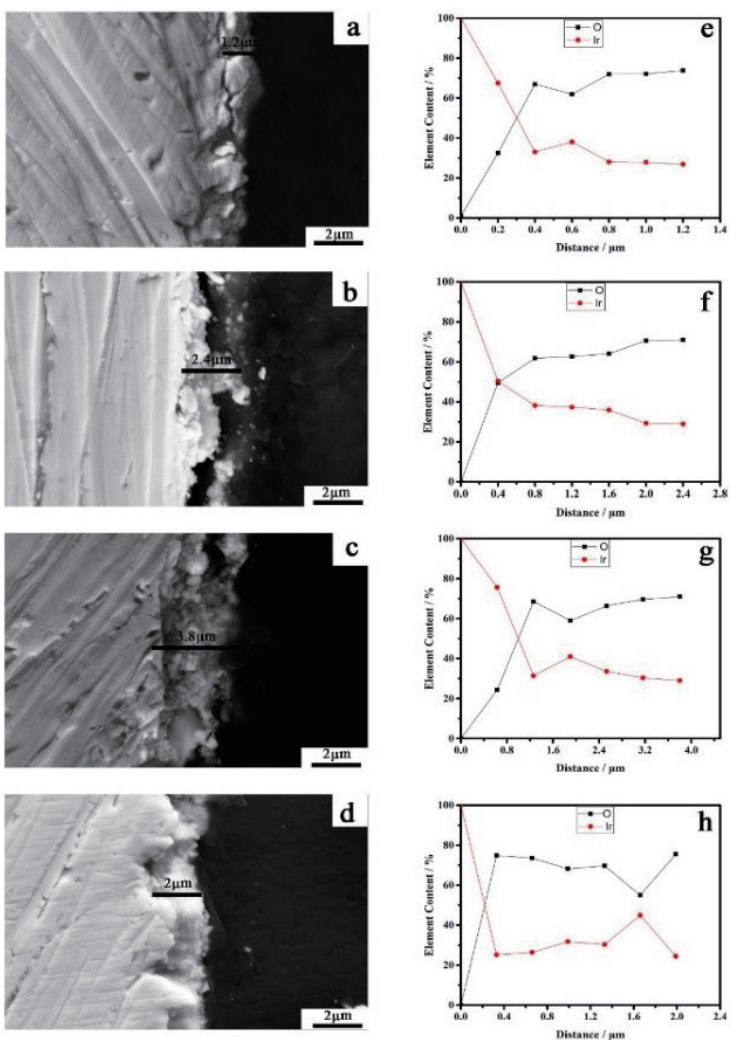

$(5-1)$
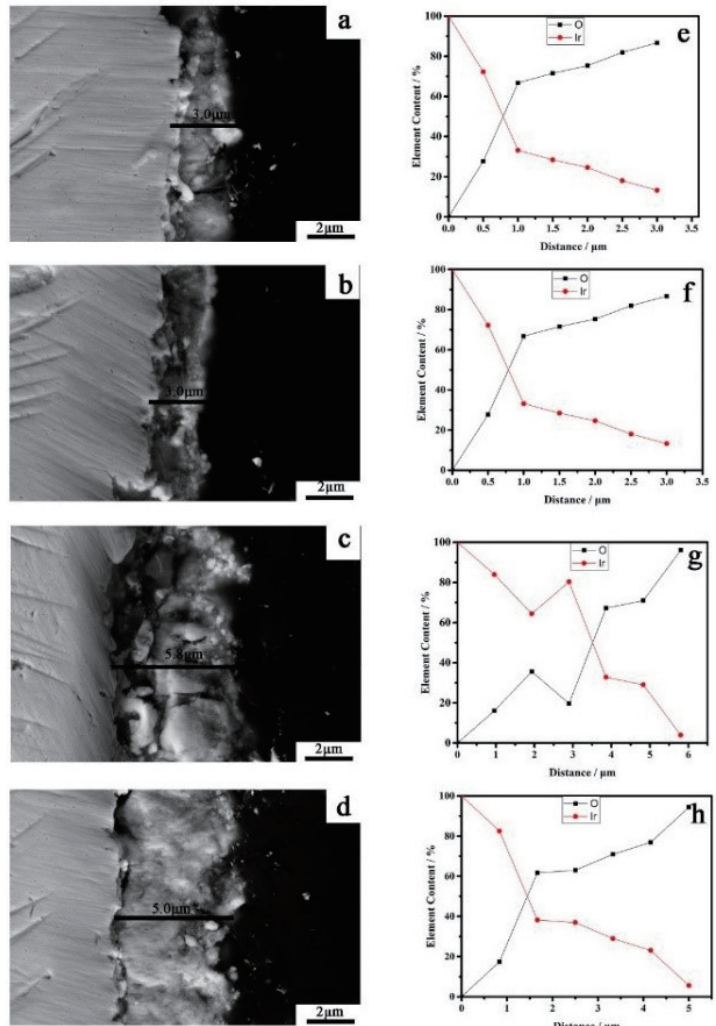

$(5-3)$
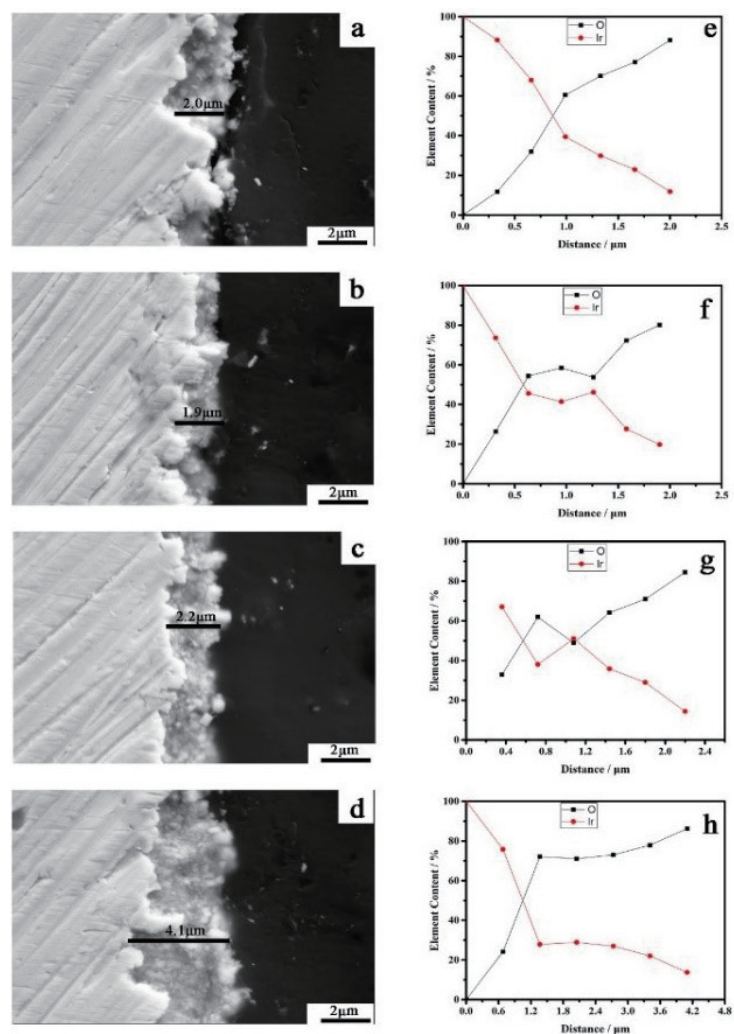

$(5-2)$
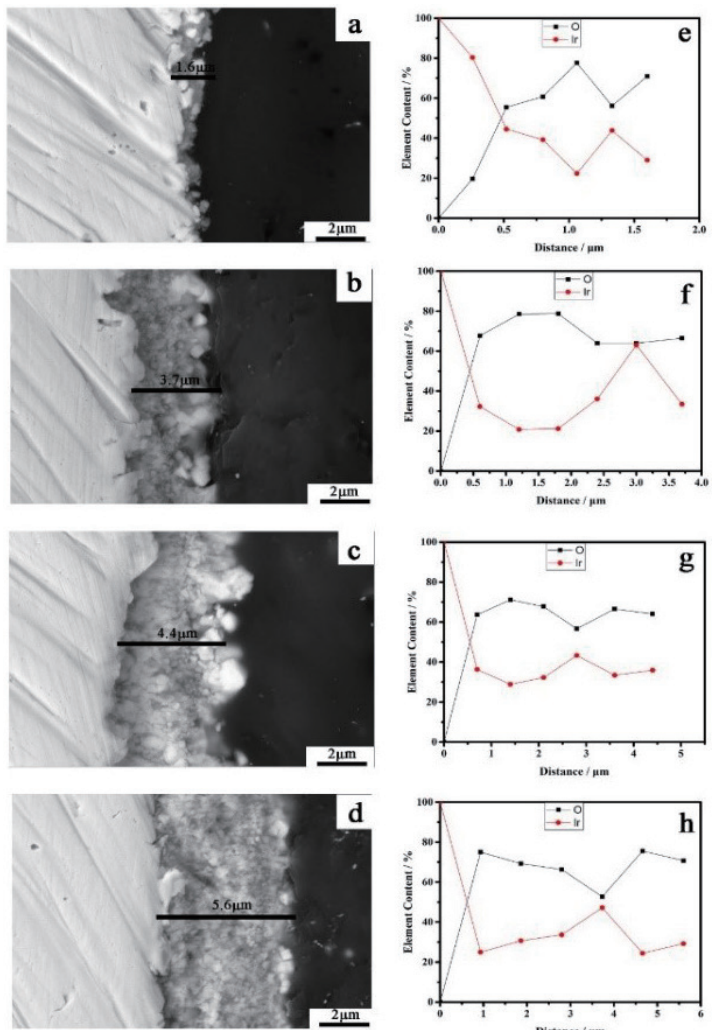

$(5-4)$

Fig. 5. (Color online) Cross-sectional images and corresponding element distributions of the $\operatorname{IrO}_{x}$ electrodes heated at (5-1) 700, (5-2) 750, (5-3) 800, and (5-4) $870{ }^{\circ} \mathrm{C}$ for (a) 0.5 , (b) 1.0, (c) 1.5, and (d) $2.0 \mathrm{~h}$. (e), (f), (g), and (h) show the corresponding content distributions of oxygen $(\mathbf{a})$ and iridium $(\bullet)$ in the $\mathrm{IrO}_{x}$ films as functions of the distance from the Ir substrate. 

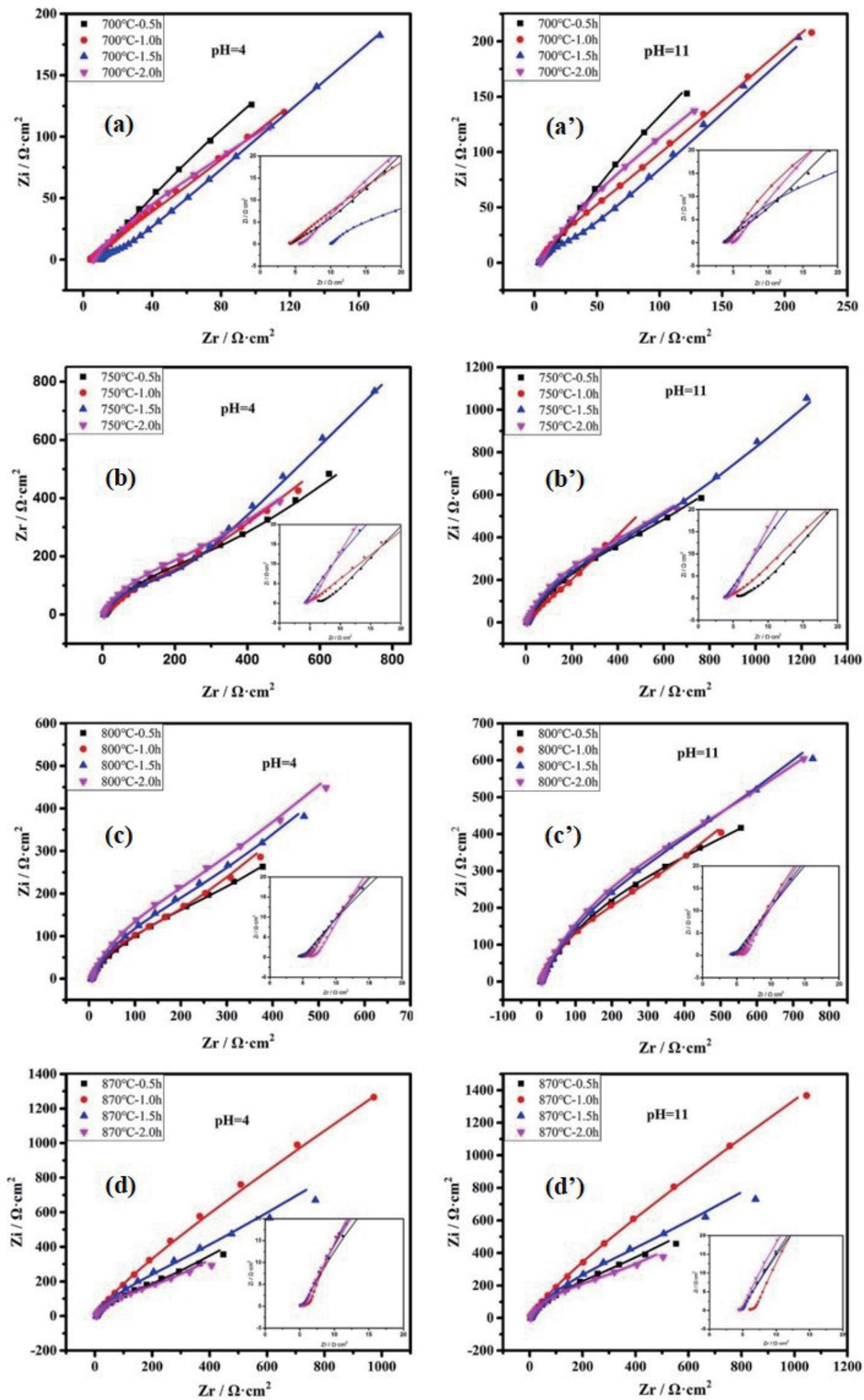

Fig. 6. (Color online) Nyquist plots of the $\mathrm{IrO}_{x}$ electrodes heated at (a, a') 700, (b, b') 750, (c, c') 800, and (d, d') $870{ }^{\circ} \mathrm{C}$ for $(\bullet) 0.5,(\bullet) 1.0,(\boldsymbol{\Delta}) 1.5$, and $(\boldsymbol{\nabla}) 2.0 \mathrm{~h}$ then immersed in $\mathrm{pH} 4$ and $\mathrm{pH} 11$ buffer solutions. The solid symbols are the experimental data, while the lines are the fitting results. 
band represent the properties of the $\mathrm{IrO}_{x}$ films, while those at low frequencies correspond to the $\mathrm{H}^{+}$response process, namely, the electrochemical response of the fabricated electrodes. ${ }^{(38,39)}$ Moreover, a diffusion tail appeared in the low-frequency band of the Nyquist plots, reflecting a mass transport process.

According to the experimental EIS plots and the practical electrochemical response process, the equivalent circuit (EC) model $\mathrm{R}(\mathrm{QR})(\mathrm{Q}(\mathrm{RW}))$ [Fig. 7(a)] was chosen and used to fit the data, where R1 is the solution resistance, R2 is the film resistance, R3 is the resistance of the $\mathrm{pH}$ response reaction, and $\mathrm{W}$ is the Warburg resistance. A constant phase element (CPE) is employed in order to eliminate the dispersion of the system, which can describe the frequency dispersion of time constants due to the local inhomogeneity, porosity, and roughness of the electrode surface. According to the actual structure and composition of the $\mathrm{IrO}_{x}$ film (Fig. 5), a model in Fig. 7(b) indicating a gradually varied composition and porous-structured $\mathrm{IrO}_{x}$ film was proposed. $\mathrm{H}^{+}$was transported from the outer layer to the inner layer of the oxide film, and the electrochemical reaction took place at the solution/film interface. As shown in Fig. 7(a), the proposed EC fitted the experimental data well. The fitting results presented in Table 2 demonstrate that the resistances of the $\mathrm{IrO}_{x}$ films fabricated by direct thermal oxidation are low $\left(<20 \Omega \cdot \mathrm{cm}^{2}\right)$, and the reaction resistances of the fabricated electrodes in the $\mathrm{pH}$ buffer solutions are within $2000 \Omega \cdot \mathrm{cm}^{2}$. The reaction and $\mathrm{IrO}_{x}$ film resistances are both lower than those of other $\mathrm{pH}$ electrodes fabricated by other methods, ${ }^{(30)}$ indicating that a $\mathrm{pH}$ response reaction readily occurs. Note that the resistance of the films is far lower than that of a traditional glass $\mathrm{pH}$ electrode. This means that the electrode reaction can occur more quickly and reach a steady state in a shorter time.

It is apparent that the reaction resistance $R_{c t}$ in the acid electrolyte is lower than that in the alkaline electrolyte, indicating a much easier occurrence of the $\mathrm{pH}$ response reaction for most of the cases. This result can also correspond to the response rates indicated previously. Specifically, when the $\mathrm{IrO}_{x}$ electrodes are fabricated at 700,750 , and $800{ }^{\circ} \mathrm{C}$ for $0.5 \mathrm{~h}$, the electrodes have relatively high reaction resistances in the $\mathrm{pH} 4$ and $\mathrm{pH} 11$ buffers. The reaction

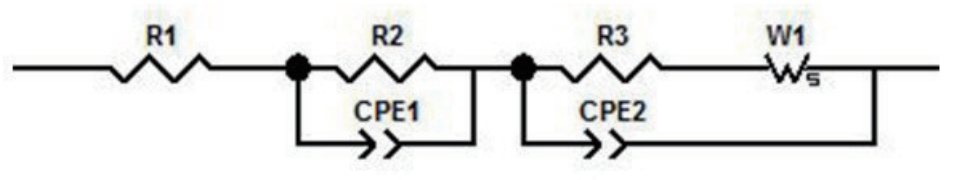

(a)

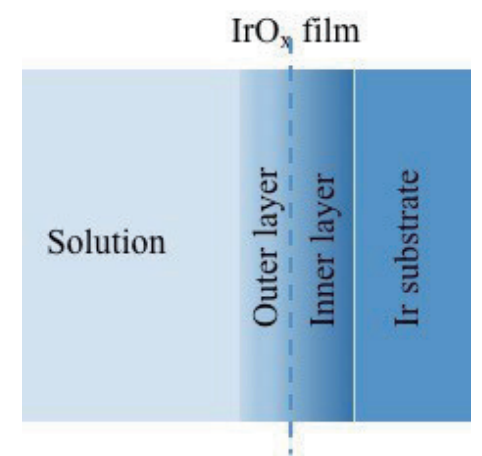

(b)

Fig. 7. (Color online) (a) EC model $\mathrm{R}(\mathrm{QR})\left(\mathrm{Q}(\mathrm{RW})\right.$ ) and (b) interface modulation of the $\mathrm{IrO}_{x}$ electrode surface film when the electrode is immersed in $\mathrm{pH}$ buffer solution. $\mathrm{R} 1$ is the solution resistance, $\mathrm{R} 2$ is the film resistance, and $\mathrm{R} 3$ is the reaction resistance. (CPE1 is constant phase element 1, reflecting the capacitance property of the $\mathrm{IrO}_{x}$ film, CPE2 is constant phase element 2, reflecting the capacitance property of the response reaction, and W1 is the Warburg resistance.) 
Table 2

Fitting parameters for the $\mathrm{EC}$ model $\mathrm{R}(\mathrm{QR})(\mathrm{Q}(\mathrm{RW}))$ obtained in $\mathrm{pH} 4$ and $\mathrm{pH} 11$ buffer solutions.

\begin{tabular}{|c|c|c|c|c|c|c|}
\hline \multirow{3}{*}{$\begin{array}{l}\text { Heat treatment } \\
\text { conditions }\end{array}$} & \multicolumn{3}{|c|}{$\mathrm{pH}=4$} & \multicolumn{3}{|c|}{$\mathrm{pH}=11$} \\
\hline & R1 & R2 & R3 & R1 & R2 & R3 \\
\hline & $/ \Omega \cdot \mathrm{cm}^{2}$ & $/ \Omega \cdot \mathrm{cm}^{2}$ & $/ \Omega \cdot \mathrm{cm}^{2}$ & $/ \Omega \cdot \mathrm{cm}^{2}$ & $/ \Omega \cdot \mathrm{cm}^{2}$ & $/ \Omega \cdot \mathrm{cm}^{2}$ \\
\hline $700^{\circ} \mathrm{C}-0.5 \mathrm{~h}$ & 5.493 & 4.199 & 1427.0 & 4.664 & 3.786 & 1491.0 \\
\hline $700{ }^{\circ} \mathrm{C}-1.0 \mathrm{~h}$ & 4.246 & 4.452 & 114.2 & 19.370 & 3.934 & 129.4 \\
\hline $700^{\circ} \mathrm{C}-1.5 \mathrm{~h}$ & 8.085 & 10.020 & 163.8 & 6.588 & 2.950 & 303.3 \\
\hline $700{ }^{\circ} \mathrm{C}-2.0 \mathrm{~h}$ & 5.360 & 6.454 & 158.2 & 5.530 & 1.846 & 269.8 \\
\hline $750^{\circ} \mathrm{C}-0.5 \mathrm{~h}$ & 13.430 & 4.800 & 1299.0 & 11.100 & 4.874 & 763.1 \\
\hline $750{ }^{\circ} \mathrm{C}-1.0 \mathrm{~h}$ & 12.020 & 4.338 & 383.0 & 8.747 & 3.297 & 172.9 \\
\hline $750{ }^{\circ} \mathrm{C}-1.5 \mathrm{~h}$ & 4.182 & 10.510 & 143.2 & 8.919 & 2.185 & 672.3 \\
\hline $750{ }^{\circ} \mathrm{C}-2.0 \mathrm{~h}$ & 6.333 & 3.641 & 266.9 & 5.505 & 2.913 & 584.4 \\
\hline $800^{\circ} \mathrm{C}-0.5 \mathrm{~h}$ & 6.821 & 4.899 & 391.4 & 6.467 & 4.637 & 785.2 \\
\hline $800^{\circ} \mathrm{C}-1.0 \mathrm{~h}$ & 1.731 & 4.784 & 201.1 & 1.895 & 4.151 & 361.9 \\
\hline $800^{\circ} \mathrm{C}-1.5 \mathrm{~h}$ & 7.505 & 3.567 & 309.5 & 1.357 & 3.962 & 740.1 \\
\hline $800^{\circ} \mathrm{C}-2.0 \mathrm{~h}$ & 8.163 & 4.922 & 282.8 & 7.435 & 5.848 & 741.0 \\
\hline $870{ }^{\circ} \mathrm{C}-0.5 \mathrm{~h}$ & 6.336 & 10.000 & 230.7 & 5.638 & 0.100 & 395.4 \\
\hline $870{ }^{\circ} \mathrm{C}-1.0 \mathrm{~h}$ & 7.084 & 2.908 & 124.5 & 7.598 & 4.129 & 165.8 \\
\hline $870{ }^{\circ} \mathrm{C}-1.5 \mathrm{~h}$ & 6.610 & 0.100 & 322.1 & 4.828 & 0.160 & 345.3 \\
\hline $870{ }^{\circ} \mathrm{C}-2.0 \mathrm{~h}$ & 6.223 & 5.280 & 617.7 & 5.272 & 0.100 & 527.6 \\
\hline
\end{tabular}

impedance of the electrodes prepared at these temperatures decreases significantly as the heating time increases from 0.5 to $1.5 \mathrm{~h}$. The sample heated at $870{ }^{\circ} \mathrm{C}$ for $2 \mathrm{~h}$ shows a relatively high reaction resistance in the above $\mathrm{pH}$ buffers, while the other electrodes fabricated at this temperature show a lower reaction resistance (Table 2).

To summarize, the $\mathrm{IrO}_{x}$ electrodes fabricated by direct thermal oxidation, i.e., heated at 700,750 , and $800{ }^{\circ} \mathrm{C}$ for more than $1.0 \mathrm{~h}$ or at $870{ }^{\circ} \mathrm{C}$ for less than $2.0 \mathrm{~h}$, have a relatively low reaction resistance. Therefore, the following characterization tests on the $\mathrm{IrO}_{x}$ electrodes fabricated under these conditions were carried out.

\subsubsection{Surface roughness tests}

The response rate/electrode reaction rate of the $\mathrm{IrO}_{x}$ electrodes strongly depends on the effective electrode area. However, the effective area of a porous $\mathrm{IrO}_{x}$ electrode is difficult to estimate; thus, the surface roughness $(R a)$ is used to assess the effective area of the $\operatorname{IrO}_{x}$ electrodes instead. The representative results of local surface roughness tests for the electrodes produced by heating at $700,750,800$, and $870{ }^{\circ} \mathrm{C}$ for $1.5 \mathrm{~h}$ are shown in Fig. 8, where the average surface roughness and corresponding error bars obtained by measuring the surface roughness at five different places are shown in Fig. 9.

The $\mathrm{IrO}_{x}$ electrode fabricated at $800^{\circ} \mathrm{C}$ for $1.5 \mathrm{~h}$ has the largest $\mathrm{R} a$ among the $\mathrm{IrO}_{x}$ electrodes prepared at different temperatures. The average surface roughness results illustrated in Fig. 9 indicate that the surface roughness increases with the heating temperature up to $800{ }^{\circ} \mathrm{C}$, then saturates. In addition to the largest surface roughness, the $\mathrm{IrO}_{x}$ electrodes obtained at $800{ }^{\circ} \mathrm{C}$ have the smallest error, indicating a higher uniformity and a larger effective surface area for the electrochemical process. 

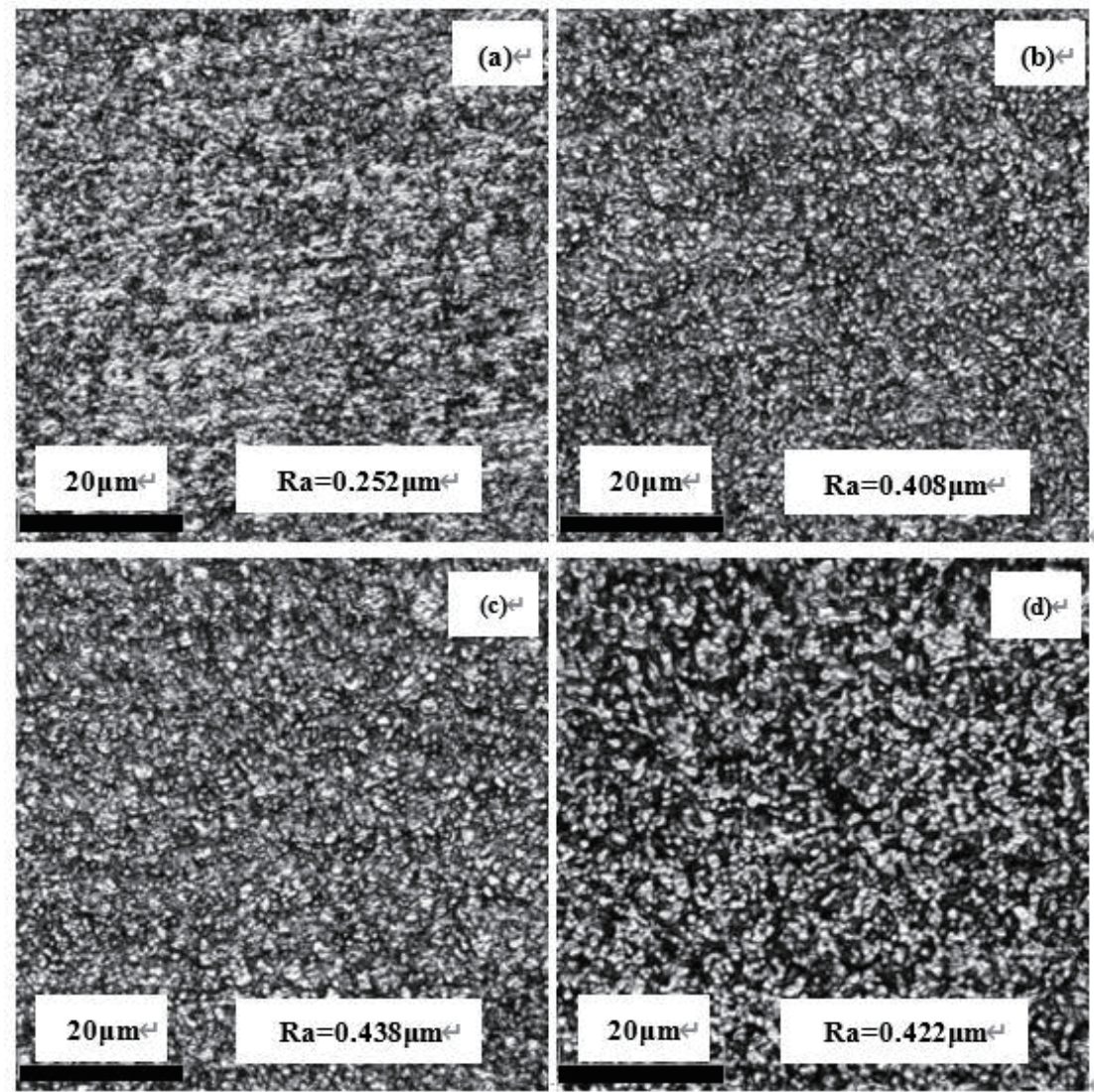

Fig. 8. Typical surface roughness figures of the $\mathrm{IrO}_{x}$ electrodes prepared at (a) 700, (b) 750 , (c) 800 , and (d) $870{ }^{\circ} \mathrm{C}$ for $1.5 \mathrm{~h}$.

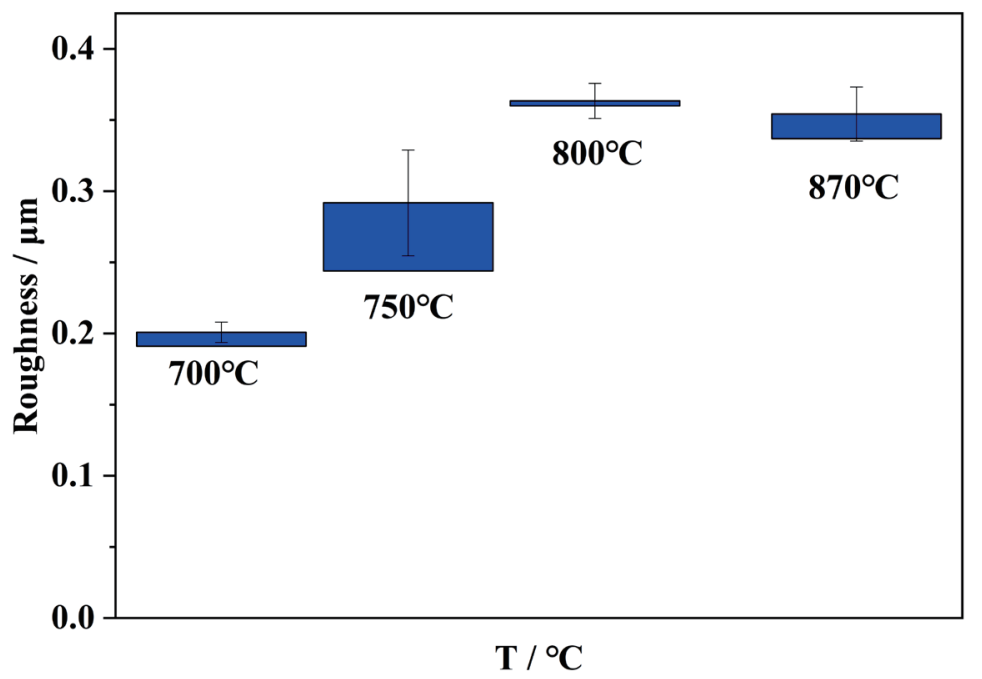

Fig. 9. (Color online) Surface roughness error bar plots of $\mathrm{IrO}_{x}$ electrodes prepared at different heating temperatures. 


\subsubsection{XPS tests}

The surface composition and elemental chemical state of the $\mathrm{IrO}_{x}$ electrodes fabricated at $700,750,800$, and $870{ }^{\circ} \mathrm{C}$ for $1.5 \mathrm{~h}$ were analyzed by XPS. The $\mathrm{Ir} 4 \mathrm{f}$ and $\mathrm{O}$ 1s absorption spectra collected and their deconvolutions are displayed in Figs. 10 (a, a') $\left(700^{\circ} \mathrm{C}\right),\left(\mathrm{b}, \mathrm{b}^{\prime}\right)\left(750^{\circ} \mathrm{C}\right)$, (c, c') $\left(800^{\circ} \mathrm{C}\right)$, and $\left(\mathrm{d}, \mathrm{d}^{\prime}\right)\left(870{ }^{\circ} \mathrm{C}\right)$. The bold black lines are the experimental results and the dash and dot lines are the results obtained after deconvolution. With the deconvoluted data, a detailed analysis was carried out. The BEs of Ir and O obtained in our experiment and in the literature are summarized in Table 3. By referring to the data in the table, the valences of Ir and $\mathrm{O}$ and the existential form of the elements were recognized.

The deconvoluted $\mathrm{Ir}$ 4f spectrum acquired from the $\mathrm{IrO}_{x}$ electrode fabricated at $700{ }^{\circ} \mathrm{C}$ [Fig. 10(a)] shows structures at $61.75 \mathrm{eV}(4 \mathrm{f}(7 / 2))$ and $64.7 \mathrm{eV}(4 \mathrm{f}(5 / 2))$, which correspond to $\mathrm{Ir}^{3+}$, while the structures at $62.52 \mathrm{eV}(4 \mathrm{f}(7 / 2))$ and $65.47 \mathrm{eV}(4 \mathrm{f}(5 / 2))$ reflect the presence of $\mathrm{Ir}^{4+}$, and the structures at $64.35 \mathrm{eV}(4 \mathrm{f}(7 / 2))$ and $67.30 \mathrm{eV}(4 \mathrm{f}(5 / 2))$ are close to the binding energy of $\operatorname{~rr}^{6+}$. The last two structures are defective, resulting from the high-temperature heat treatment, and do not contribute to the $\mathrm{H}^{+}$response process. ${ }^{(41)}$ The ratio of the different valences of Ir was calculated from the areas of the different deconvoluted peaks within a spectrum. The content of $\mathrm{Ir}^{3+}$ from the $\mathrm{IrO}_{x}$ electrode fabricated at $700{ }^{\circ} \mathrm{C}$ is 0.1691 , that of $\mathrm{Ir}^{4+}$ is 0.6365 , and that of $\mathrm{Ir}^{6+}$ is 0.1944 . Similar results were obtained from the electrodes fabricated at 750,800 , and $870{ }^{\circ} \mathrm{C}$; details are given in Table 3.

$\mathrm{O}$ 1s spectra of the $\mathrm{IrO}_{x}$ electrodes fabricated at different temperatures and their deconvolutions are illustrated in Figs. 10(a')-10(d'). The deconvoluted peaks of the $\mathrm{O} 1 \mathrm{~s}$ spectrum obtained from the $\mathrm{IrO}_{x}$ electrode fabricated at $700{ }^{\circ} \mathrm{C}$ [Fig. $10\left(\mathrm{a}^{\prime}\right)$ ] are located at $529.07,530.63$, and $532.70 \mathrm{eV}$, which are assigned to a lattice of oxidized $\mathrm{O}^{2-}$ ions, hydroxide or bound water, and adsorbed $\mathrm{H}_{2} \mathrm{O}$ or $\mathrm{O}_{2}$, respectively. The peak located at $529.07 \mathrm{eV}$ is ascribed to high-temperature oxidation, while the peak at $530.63 \mathrm{eV}$ is caused by water

Table 3

BEs of Ir and O determined in our XPS study and in the literature.

\begin{tabular}{|c|c|c|c|c|c|c|c|}
\hline & \multicolumn{3}{|c|}{ BEs of $\operatorname{Ir}(4 \mathrm{f} 7 / 2,4 \mathrm{f} 5 / 2) / \mathrm{eV}$} & \multicolumn{3}{|c|}{ BEs of $\mathrm{O}(1 \mathrm{~s}) / \mathrm{eV}$} \\
\hline & & $\operatorname{Ir}^{3+}$ & $\mathrm{Ir}^{4+}$ & $\operatorname{Ir}^{6+}$ & Oxide & $\begin{array}{l}\text { Hydroxide or } \\
\text { bound water }\end{array}$ & $\mathrm{H}_{2} \mathrm{O} \mathrm{O}_{2}$ \\
\hline \multicolumn{2}{|c|}{$\begin{array}{l}\text { Literature } \\
\text { data }\end{array}$} & $61.6,64.55^{(38-41)}$ & $62.7,65.65^{(38-41)}$ & $64.3,67.25^{(38-41)}$ & $528.1-531^{(42)}$ & $530.6-532^{(42)}$ & $532.5-533.5^{(42)}$ \\
\hline \multirow{12}{*}{ 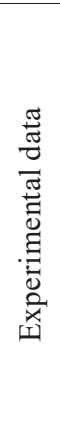 } & \multirow{3}{*}{700} & $61.75,64.7$ & $62.52,65.47$ & $64.35,67.3$ & 529.07 & 530.63 & 532.7 \\
\hline & & & Relative content & & & Relative conte & \\
\hline & & 0.1691 & 0.6365 & 0.1944 & 0.1293 & 0.7423 & 0.1284 \\
\hline & \multirow{3}{*}{750} & $61.56,64.51$ & $62.48,65.43$ & $64.23,67.18$ & 529.26 & 530.78 & 532.9 \\
\hline & & & Relative content & & & Relative conte & \\
\hline & & 0.3982 & 0.4755 & 0.1263 & 0.1067 & 0.7692 & 0.1241 \\
\hline & \multirow{3}{*}{800} & $61.6,64.55$ & $62.51,65.46$ & $64.3,67.25$ & 529.8 & 531.08 & 532.8 \\
\hline & & & Relative content & & & Relative conte & \\
\hline & & 0.4339 & 0.4247 & 0.1414 & 0.3745 & 0.5246 & 0.1009 \\
\hline & \multirow{3}{*}{870} & $61.78,64.72$ & $62.88,65.82$ & $64.25,67.2$ & 529.1 & 530.65 & 532.9 \\
\hline & & & Relative content & & & Relative conter & \\
\hline & & 0.4587 & 0.3254 & 0.2159 & 0.1977 & 0.6987 & 0.1036 \\
\hline
\end{tabular}



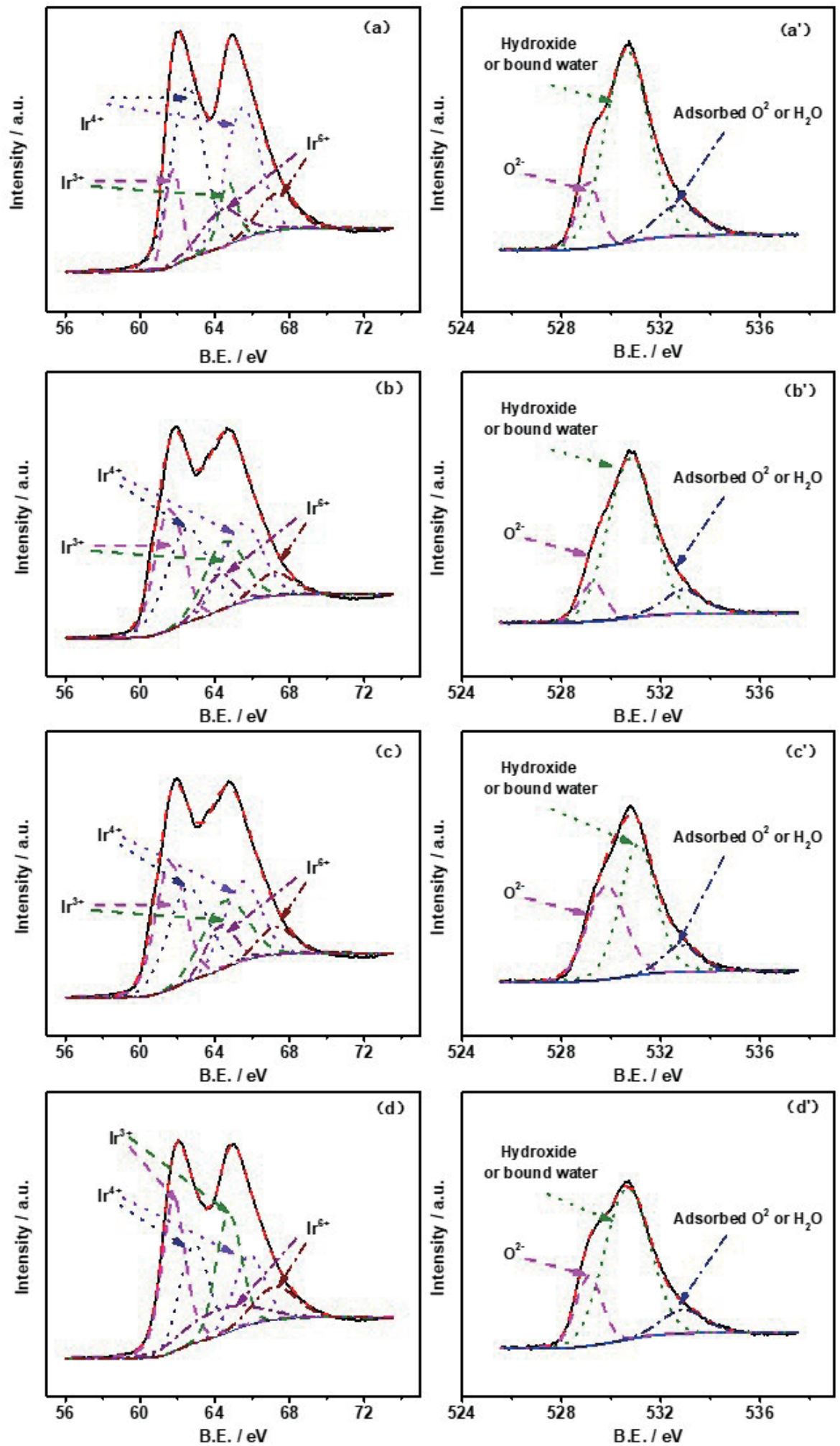

Fig. 10. (Color online) XPS results of the $\operatorname{IrO}_{x}$ electrodes fabricated at (a, a') 700, (b, b') 750, (c, c') 800, and (d, d') $870{ }^{\circ} \mathrm{C}$ for $1.5 \mathrm{~h}$, where (a), (b), (c), and (d) are Ir $4 \mathrm{f}$ spectra and (a'), (b'), (c'), and (d') are $\mathrm{O}$ 1s spectra. Bold black lines are the measured results and broken lines are the fitted results. 
quenching or hydration during soaking. Similarly, the spectra for the other three fabrication conditions [Figs. 10(b')-10(d')] can be deconvoluted into three peaks, namely, a lattice of oxidized $\mathrm{O}^{2-}$ ions, hydroxide or bound water, and adsorbed $\mathrm{H}_{2} \mathrm{O}$ or $\mathrm{O}_{2}$, whose specific binding energy and relative content can be seen in Table 3 .

In summary, the element $\mathrm{Ir}$ exists as $\mathrm{Ir}^{3+}, \mathrm{Ir}^{4+}$, and $\mathrm{Ir}^{6+}$ in the $\mathrm{IrO}_{x}$ surface films fabricated at different temperatures, whereas the element $\mathrm{O}$ exists as $\mathrm{O}^{2-}$, hydroxide or bound water, and adsorbed $\mathrm{H}_{2} \mathrm{O}$ or $\mathrm{O}_{2}$. Therefore, the electrode surface comprises oxides and hydroxides of Ir with different valences. The binding energy varies among the different valences of Ir and among the different fabricated samples, which may be due to the different heat treatment temperatures and heating times. The different substances, namely, the lattice of oxidized $\mathrm{O}^{2-}$ ions, hydroxide or bound water, and adsorbed $\mathrm{H}_{2} \mathrm{O}$ or $\mathrm{O}_{2}$, combined with $\operatorname{Ir}^{n+}(n=3,4,6)$, resulting in the differences among the proportions of the ions.

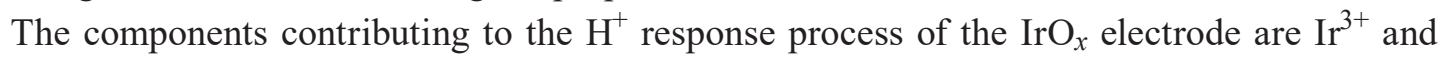
$\mathrm{Ir}^{4+}$, whereas $\mathrm{Ir}^{6+}$ was considered as a defective component by Kim et al., which does not contribute to the $\mathrm{H}^{+}$response process, ${ }^{(41)}$ thus, the amount of $\mathrm{Ir}^{6+}$ in the fabricated electrode

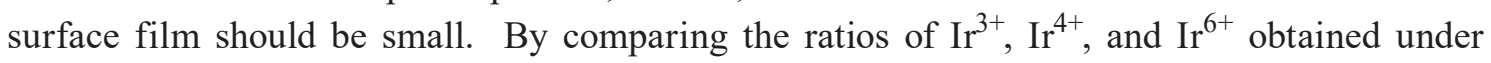
all the fabrication conditions (Table 3), it can be seen that the electrodes fabricated at 750 and $800{ }^{\circ} \mathrm{C}$ have a small amount of the defective component $\operatorname{Ir}^{6+}$. As a result, heat treatment at 750 and $800{ }^{\circ} \mathrm{C}$ is recommended for obtaining $\mathrm{IrO}_{x}$ electrodes with a greater $\mathrm{H}^{+}$response. Upon further increasing the heating temperature, the content of adsorbed $\mathrm{O}_{2}$ decreases and the contents of oxide and hydroxide increase. The $\mathrm{IrO}_{x}$ electrodes fabricated at 800 and $870{ }^{\circ} \mathrm{C}$ have higher oxidation degrees, resulting in the formation of more oxide and hydroxide, which is advantageous for accelerating the electrode response process.

\subsection{Discussion about factors affecting the response property of the $\mathrm{IrO}_{x}$ electrodes}

The performance of a $\mathrm{pH}$ electrode determines its potential for application. Among the evaluated properties of the $\mathrm{pH}$ electrodes, the $E-\mathrm{pH}$ response, response time, and long-term stability are the most important. As stated earlier, all the electrodes fabricated by direct thermal oxidation show good linear $E-\mathrm{pH}$ response, and the electrodes fabricated for 1.0 or $1.5 \mathrm{~h}$ have a relatively high response rate and good long-term stability regardless of the fabrication temperature. With increasing heating time at a certain temperature, the variation in electrode potential tends to markedly decrease. This can be ascribed to the variation in hydration degree and also the ratio of $\mathrm{Ir}^{4+} / \mathrm{Ir}^{3+}$ within the surface $\mathrm{IrO}_{x}$ film. The $\mathrm{Ir}^{4+} / \mathrm{Ir}^{3+}$ ratio was determined by the heat treatment process, whereas the hydration degree of the $\mathrm{IrO}_{x}$ film continually changed during the soaking of the $\mathrm{IrO}_{x}$ electrodes. A relatively long heating time, such as 1.0 or $1.5 \mathrm{~h}$, resulted in a thicker and more porous surface film, further accelerating the hydration process. The EIS tests indicate a negligible difference among the film resistances of the different $\operatorname{IrO}_{x}$ electrodes, whose values are far less than that of a glass $\mathrm{pH}$ electrode. The reaction resistances of the electrodes fabricated for 1.0 and $1.5 \mathrm{~h}$ are relatively low at all temperatures, indicating that the electrodes can show a faster response to $\mathrm{H}^{+}$.

Sectional morphology observations revealed that the thickness of the $\operatorname{IrO}_{x}$ film generally increases with the heating temperature and time (up to $1.5 \mathrm{~h}$ ), whereas an appropriate thickness 
of the surface $\mathrm{IrO}_{x}$ film ensures good reproducibility and long-term stability of the electrodes. Therefore, it is necessary to control the heating temperature and heating time during fabrication. In addition to obtaining an excellent response, the adhesion between the surface $\mathrm{IrO}_{x}$ film and the substrate, and the strength of the surface film should also be guaranteed. From the morphologies of the $\mathrm{IrO}_{x}$ electrode surfaces, too many cracks existed on the surface of the electrodes fabricated at $700{ }^{\circ} \mathrm{C}$, although fewer or no cracks were observed at higher heating temperatures. Thus, it is reasonable to use a heating temperature above $750{ }^{\circ} \mathrm{C}$ and a heating time longer than $1 \mathrm{~h}$ when fabricating $\mathrm{IrO}_{x}$ electrodes by this direct thermal oxidation method.

$$
2\left[\mathrm{IrO}_{2}(\mathrm{OH})_{2} \cdot 2 \mathrm{H}_{2} \mathrm{O}\right]^{2-} \cdot 2 \mathrm{H}^{+}+2 \mathrm{e}^{-}+2 \mathrm{H}^{+} \leftrightarrow\left[\mathrm{Ir}_{2} \mathrm{O}_{3}(\mathrm{OH})_{3} \cdot 3 \mathrm{H}_{2} \mathrm{O}\right]^{3-} \cdot 3 \mathrm{H}^{+}+3 \mathrm{H}_{2} \mathrm{O}
$$

The composition analysis (Fig. 10, Table 3) of the electrodes fabricated at different temperatures for $1.5 \mathrm{~h}$ revealed that the $\mathrm{IrO}_{x}$ electrode with the best response reaction comprised oxides and hydroxides of $\mathrm{Ir}^{3+}$ and $\mathrm{Ir}^{4+}$. The response reaction is mainly the transformation between compounds of $\mathrm{Ir}^{4+}$ and $\mathrm{Ir}^{3+}$ within the films of the $\mathrm{IrO}_{x}$ electrodes, during which the $\mathrm{H}^{+}$ response is realized [Eq. (1)]. ${ }^{(32)}$ Therefore, more $\mathrm{Ir}^{4+}$ and $\mathrm{Ir}^{3+}$ are desirable during fabrication. The $\mathrm{IrO}_{x}$ electrodes fabricated at 750 and $800{ }^{\circ} \mathrm{C}$ have less $\mathrm{Ir}^{6+}$ and more $\mathrm{Ir}^{3+}$ and $\mathrm{Ir}^{4+}$. The oxide and hydroxide contents increase with the fabrication temperature, indicating that the $\mathrm{IrO}_{x}$ electrodes fabricated at $800{ }^{\circ} \mathrm{C}$ and $870{ }^{\circ} \mathrm{C}$ have a higher oxidation degree, which is expected during the electrode response process. It is also verified that an appropriate fabrication temperature and introducing a subsequent quenching process help to obtain an $\mathrm{IrO}_{x}$ electrode with a larger surface roughness and a larger effective area for the electrochemical process. As a result, heat treatment at $800{ }^{\circ} \mathrm{C}$ for $1.5 \mathrm{~h}$ is recommended to obtain $\mathrm{IrO}_{x}$ electrodes with good comprehensive performance, including a larger composition with a $\mathrm{H}^{+}$response, a lower reaction resistance, a higher response rate, and a higher long-term stability.

Although the $\mathrm{IrO}_{x}$ electrodes fabricated by direct thermal oxidation exhibit good $E-\mathrm{pH}$ response, the insufficient surface oxidation of the iridium generates a thinner $\mathrm{IrO}_{x}$ film, which may result in a higher reaction resistance, leading to a longer response time. Therefore, further optimization of the fabrication process of $\mathrm{IrO}_{x}$ electrodes should concentrate on producing porous electrodes with a larger surface area and a more suitable oxidation degree.

\section{Conclusions}

$\mathrm{IrO}_{x} \mathrm{pH}$ electrodes were fabricated by direct thermal oxidation with different heating temperatures $\left(700,750,800\right.$, and $\left.870{ }^{\circ} \mathrm{C}\right)$ and heating times $(0.5,1.0,1.5$, and $2.0 \mathrm{~h})$. All the fabricated electrodes showed an excellent Nernstian response. The electrodes heated for 1.0 and $1.5 \mathrm{~h}$ had a relatively high response rate and good long-term stability regardless of the heating temperature. The developed $\mathrm{pH}$ electrodes responded faster in acid electrolyte than in alkaline electrolyte.

The $\mathrm{IrO}_{x}$ electrodes were characterized to determine the factors that affected their performance. Relatively low heating temperatures $\left(700\right.$ and $\left.750{ }^{\circ} \mathrm{C}\right)$ resulted in the inadequate oxidation of the $\mathrm{IrO}_{x}$ electrodes regardless of the heating time. The corresponding generated surface oxide films were thinner, had smaller surface roughnesses, and more cracks on the 
surface, which may result in a higher reaction resistance, a longer response, and the lack of rigidity.

Moreover, the electrodes fabricated at the highest temperature of $870{ }^{\circ} \mathrm{C}$ did not show significantly improved properties, and this temperature is also not recommended owing to the generation of too much of the defective composition on the electrode surface and also from the perspective of energy saving and environmental protection. Therefore, to fabricate $\operatorname{IrO}_{x}$ electrodes with good comprehensive $\mathrm{pH}$ response properties, heat treatment at $800{ }^{\circ} \mathrm{C}$ for $1.5 \mathrm{~h}$ is suggested for producing a composition with a more effective response and a larger surface roughness, resulting in the generation of a surface film with suitable thickness and a better electrode structure.

\section{Acknowledgments}

We are grateful for the support from Beijing Municipal of Science and Technology (ID: Z201100004520011) and Fundamental Research Funds for Central Universities (Project ID: FRF-TP-19-011A2). We are also grateful to have the support from the 111 Project (grant No. B12012) for promoting international exchange.

\section{References}

1 A. Fog and R. P. Buck: Sens. Actuators 5 (1984) 137. https://doi.org/10.1016/0250-6874(84)80004-9

2 S. Yao, M. Wang, and M. Madou: J. Electrochem. Soc. 148 (2001) H29. https://iopscience.iop.org/ article/10.1149/1.1353582

3 Y. H. Liao and J. C. Chou: Sens. Actuators, B 128 (2008) 603. https://doi.org/10.1016/j.snb.2007.07.023

4 N. Tsai, J. C. Chou, T. P. Sun, and S. K. Hsiung: Sens. Actuators, B 108 (2005) 877. https://doi.org/10.1016/ j.snb.2004.11.050

5 O. S. Wolfbeis: Anal. Chem. 80 (2008) 4269. https://doi.org/10.1021/ac800473b

6 J. G. Webster and H. Eren: Measurement, Instrumentation, and Sensors Handbook: Spatial, Mechanical, Thermal, and Radiation Measurement (CRC Press, Florida, 2014) 2nd ed.

7 J. Han, D. Cui, Y. Li, H. Zhang, Y. Huang, Z. Zheng, Y. Zhu, and X. Li: Sens. Actuators, B 66 (2000) 203. https://doi.org/10.1016/S0925-4005(00)00363-4

8 S. Dong, M. Luo, G. Peng, and W. Cheng: Sens. Actuators, B 129 (2008) 94. https://doi.org/10.1016/ j.snb.2007.07.078

9 G. Gerlach, M. Guenther, J. Sorber, G. Suchaneck, K. F. Arndt, and A. Richter: Sens. Actuators, B 111-112 (2005) 555. https://doi.org/10.1016/j.snb.2005.03.040

10 R. Bashir, J. Hilt, O. Elibol, A. Gupta, and N. Peppas: Appl. Phys. Lett. 81 (2002) 3091. https://doi. org/10.1063/1.1514825

11 N. F. Sheppard, M. J. Lesho, P. McNally, and A. S. Francomacaro: Sens. Actuators, B 28 (1995) 95. https://doi. org/10.1016/0925-4005(94)01542-P

12 Y. Liu and T. Cui: Sens. Actuators, B 123 (2007) 148. https://doi.org/10.1016/j.snb.2006.08.006

13 W. Olthuis: Sens. Actuators, B 105 (2005) 96. https://doi.org/10.1016/j.snb.2004.02.040

14 F. Huang, Y. Jin, L. Wen, D. Mu, and M. Cui: J. Electrochem. Soc. 160 (2013) B184. https://doi. org/10.1149/2.006310jes

15 M. Pourbaix: Atlas of Electrochemical Equilibria in Aqueous Solutions (National Association of Corrosion Engineers, Houston, 1974) p. 471.

16 L. D. Burke and D. Whelan: J. Electroanal. Chem. 162 (1984) 121. https://doi.org/10.1016/S00220728(84)80159-X

17 S. A. Marzouk, S. Ufer, R. P. Buck, T. A. Johnson, L. A. Dunlap, and W. E. Cascio: Anal. Chem. 70 (1998) 5054. https://doi.org/10.1021/ac980608e

18 T. Y. Kim, and S. Yang: Sens. Actuators, B 196 (2014) 31. https://doi.org/10.1016/j.snb.2014.02.004

19 R. K. Jaworski, J. A. Cox, and B. R. Strohmeier: J. Electroanal. Chem. 325 (1992) 111. https://doi. org/10.1016/0022-0728(92)80105-D 
20 P. G. Pickup and V. Birss: J. Electroanal. Chem. 220 (1987) 83. https://doi.org/10.1016/0022-0728(87)88006-3

21 J. E. Baur and T. W. Spaine: J. Electroanal. Chem. 443 (1998) 208. https://doi.org/10.1016/S00220728(97)00532-9

22 S. Gottesfeld, J. McIntyre, G. Beni, and J. Shay: Appl. Phys. Lett. 33 (1978) 208. https://doi.org/10.1063/1.90277

23 T. Katsube, I. Lauks, and J. Zemel: Sens. Actuators 2 (1981-1982) 399. https://doi.org/10.1016/02506874(81)80060-1

24 M. J. Tarlov, S. Semancik, and K. G. Kreider: Sens. Actuators, B 1 (1990) 293. https://doi.org/10.1016/09254005(90)80218-O

25 K. G. Kreider, M. J. Tarlov, and J. P. Cline: Sens. Actuators, B 28 (1995) 167. https://doi.org/10.1016/09254005(95)01655-4

26 I. Lauks, M. Yuen, and T. Dietz: Sens. Actuators 4 (1983) 375. https://doi.org/10.1016/0250-6874(83)85047-1

27 K. Izutsu, and H. Yamamoto: Anal. Sci. 12 (1996) 905. https://doi.org/10.2116/analsci.12.905

28 M. Wang, S. Yao, and M. Madou: Sen. Actuators, B 81 (2002) 313. https://doi.org/10.1016/S09254005(01)00972-8

29 M. Wang and S. Yao: Electroanalysis 15 (2003) 1606. http://doi.org/10.1002/elan.200302723

30 X. Chen, C. He, C. W. Du, X. G. Li, and M. Wu: J. Univ. Sci. \& Tech. Beijing 33 (2011) 200.

31 C. Ratanaporncharoen, M. Tabata, N. Watanagool, T. Goda, A. Matsumoto, M. Sriyudthsak, and Y. Miyahara: Sens. Mater. 30 (2018) 1175. https://doi.org/10.18494/SAM.2018.1733

32 F. Huang, Y. Jin, and L. Wen: J. Electrochem. Soc. 162 (2015) B337. https://doi.org/10.1149/2.0571512jes

33 F. Huang, Z. Wan, Y. Jin, and L. Wen: J. Electrochem. Soc. 164 (2017) B632. https://doi. $\operatorname{org} / 10.1149 / 2.0641713$ jes

34 F. Huang, Y. Jin, L. Wen, and Z. Wan: J. Electrochem. Soc. 165 (2018) B12. https://doi.org/10.1149/2.0581802jes

35 Y. S. Femenias, U. Angst, and B. Elsener: Mater. Corr. 69 (2018) 76. https://doi.org/10.1002/maco.201709715

36 Y. Pan, Z. Sun, H. He, Y. Li, L. You, and H. Zheng: Sen. Actuators, B 261 (2018) 316. https://doi.org/10.1016/ j.snb.2018.01.069

37 F. Huang, Y. Jin, L. Wen, D. Mu, and M. Cui: ECS Trans. 50 (2012) 237. https://doi.org/10.1149/05012.0237ecst

38 J. Q. Zhang and C. N. Cao: Corr. Protection. 19 (1998) 99.

39 N. Cao and J. Q. Zhang: Electrochemical Impedance Spectroscopy Introduction (Science Press, Beijing, 2002) pp. 151-166.

40 S. Hiifner and G. K. Wertheim: Phys. Rev. B 11 (1975) 678. https://doi.org/10.1103/PhysRevB.11.678

41 K. S. Kim, C. D. Sell, N. Winograd, and M. W. Breiter: Electrochemical Society Softbound Proceedings Series (Princeton, NY, 1974) p. 242.

42 C. D. Wagner, W. M. Riggs, L. E. Davis, J. F. Moulder, and G. E. Muilenberg: Handbook of X-Ray Photoelectron Spectroscopy (Perkin-Elmer Corporation, Minnesota, 1979) p. 150.

\section{About the Authors}

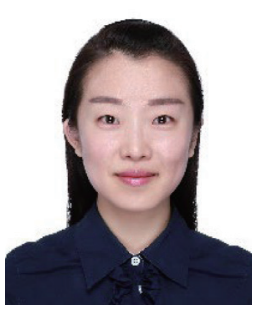

Feifei Huang received her Ph.D. degree in material science in 2016 from the University of Science and Technology Beijing (USTB). She is currently a research associate in the National Center for Materials Service Safety (NCMS) at USTB. Her field of research involves chemical sensor development, electrochemical corrosion, and the high-throughput characterization of materials. Her areas of expertise include material characterization and electrochemical analysis. (feifeihuang@ustb.edu.cn)

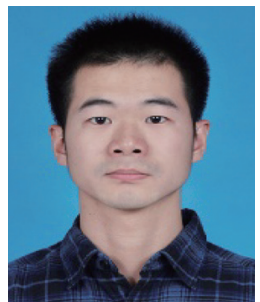

Peng Bi received his bachelor's degree in materials science and engineering in 2016 from Northwestern Polytechnical University. He received his master's degree from NCMS at USTB. He is now studying for his Ph.D. degree in Hokkaido University. His current research interests are in electrochemical corrosion and sensors. (bipeng@eng.hokudai.ac.jp) 


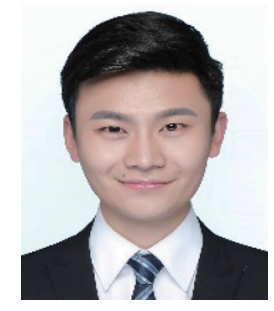

Zhengwei Wan received his master's degree in material science in 2017 at USTB. He is now a product development engineer at Zhejiang FunLithium New Energy Technology Co., Ltd. His current research interests are in sensor and electrode material development. (57743579@qq.com)

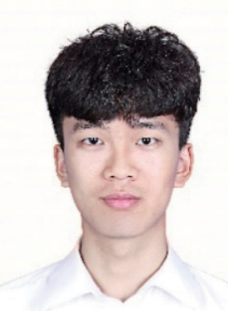

Qingrui Wang received his bachelor's degree in materials science and engineering in 2017 from Henan Polytechnic University. He is now studying for his Ph.D. degree in NCMS at USTB. His research focuses on sensors, the passivation of titanium and titanium alloys and the application of synchrotron radiation technology. (b20190452@xs.ustb.edu.cn)

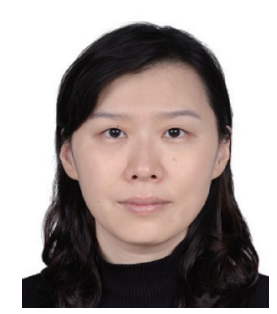

Ying Jin received her Ph.D. degree from USTB in 1998, majoring in surface finishing and corrosion electrochemistry. She is now a professor in NCMS at USTB. Before joining NCMS, she worked as a research associate at Tohoku University in 1998-1999, a postdoctoral research fellow at Toyama University in 1999-2002, a technical engineer at Matsushita Research and Development (China) Co., Ltd., in 2002-2003, and a visiting research fellow at Okayama University and Osaka Prefecture University in 2003-2005. Her research interests focus on the kinetic processes occurring on metal/electrolyte and metal/gas interfaces through state-of-the-art surface characterization and computer simulation, high-throughput multiscale corrosion experimental evaluation and modeling, the development of corrosion sensors, and the establishment of corrosion databases. (yjin@ustb.edu.cn)

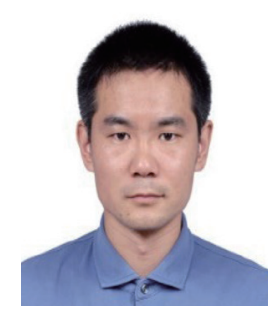

Lei Wen obtained his Ph.D. degree from Harbin Institute of Technology in 2011, majoring in material science. He is now an associate professor in NCMS at USTB. His research interests focus on sensors, the surface modification of light alloys, and the high-throughput characterization of atmospheric corrosion. (wenlei@ustb.edu.cn) 